\title{
A Crise Financeira, a Guerra Cultural e as Transformações do Espaço Econômico Brasileiro em 2009*
}

\section{Roberto Grün}

Professor do Departamento de Engenharia de Produção da Universidade Federal de São Carlos (UFSCar) e pesquisador do Núcleo de Estudos em Sociologia Econômica e das Finanças (Nesefi). E-mail: <grun@power.ufscar>

\section{INTRODUÇÃO}

D revisivelmente, a crise financeira que se anunciou no início do se1 gundo semestre de 2008 desafiou o mundo das finanças. Será ele capaz de contê-la, tratá-la e manter sua autonomia? A sociedade foi obrigada a socorrer as instituições financeiras e outras, que se fragilizaram ao extremo por causa de problemas que são diagnosticados como "excessos", ou "cupidez" dos agentes financeiros. Como evitar que as repercussões da crise façam cancelar os privilégios materiais e morais que os "mercados" e seus participantes gozaram até a eclosão da crise? Os agentes ligados ao sistema financeiro, evidentemente, irão ressaltar as vantagens e alavancagens que ele propicia à sociedade e as benfeitorias que ele promove, enquanto os críticos irão chamar a atenção para os custos diretos e indiretos da crise e irão manejar a possível repulsa ao que será considerado como remuneração excessiva, ou mesmo exorbitante, dos financistas. Haverá certamente uma disputa mais

\footnotetext{
* Esse texto é oriundo de pesquisas financiadas pelo Conselho Nacional de Desenvolvimento Científico e Tecnológico (CNPq) e pela Fundação de Amparo à Pesquisa do Estado de São Paulo (Fapesp). Agradeço às entidades pelo apoio dispensado. Agradeço, também, a Mauro Zilbovicius, Afrânio Garcia e Yves Dezalay que discutiram versões anteriores do texto, bem como aos meus jovens colegas do Núcleo de Estudos de Sociologia Econômica e das Finanças (Nesefi) da Universidade Federal de São Carlos (UFSCar), cujo entusiasmo me contamina.
}

DADOS - Revista de Ciências Sociais, Rio de Janeiro, vol. 53, n-2, 2010, pp. 255 a 297. 
direta sobre os custos da contenção da crise, cujo trailer pôde ser visto no Brasil nos anos 1990 quando, especialmente entre 1994 e 1995, o governo federal interveio em diversos bancos que apresentavam problemas diagnosticados como passíveis de criarem uma "crise sistêmica". Os maiores conglomerados em apuros naquele momento foram os bancos Nacional, Econômico e Bamerindus, hoje extintos e absorvidos por outras entidades. Eles eram bancos grandes e de alta visibilidade midiática e, para reorganizar o sistema, o governo federal da época criou o Programa de Estímulo à Reestruturação e ao Fortalecimento do Sistema Financeiro Nacional (Proer) ${ }^{1}$. As enormes somas de dinheiro necessárias para realizar o "saneamento" tornaram-se motivo de controvérsias públicas e, já naquele momento, várias questões embaraçosas foram colocadas (Nóbrega, 4/4/1997; Patury, 12/9/2001). Entre elas destacam-se as que costumam aflorar durante crises financeiras que eclodem em diversos momentos e latitudes: os diversos credores dos bancos deveriam ter seus prejuízos aliviados pela intervenção estatal ou, ao contrário, os governos deveriam deixar os bancos "quebrarem" para manter o "moral hazard" 2 ? O dinheiro gasto foi subtraído de outras possíveis despesas? Ele será recuperado? O preço pelo qual os bancos enfraquecidos, ou seus ativos, foram vendidos posteriormente refletia o valor justo ou o interesse público? O custo do salvamento do sistema financeiro é maior ou menor do que os benefícios que ele aportou à sociedade? Seria melhor aproveitar a fraqueza momentânea do sistema e estatizar aquelas instituições, já que o crédito, dadas as suas repercussões sobre a economia e a sociedade, deve ser conceituado como uma função eminentemente social?

Na especificidade da crise recente, é também bastante previsível que ocorra uma discussão sobre a continuidade da tutela que os pontos de vista financeiros têm exercido sobre a sociedade em geral, a chamada "financeirização". O bom senso financeiro instituiu uma série de verdades praticamente indiscutíveis, um senso comum compartilhado na sociedade, sobre como os governos, as empresas, os indivíduos, as organizações da sociedade civil devem se portar, destacando-se um determinado tipo de rigor orçamentário, que privilegia algumas despesas e formas de cálculo sobre outras. Assim, é óbvio que, acima de tudo, os Estados devem ter credibilidade para manter as condições de rolar a dívida pública: os credores financeiros do Estado, aqueles que lhe emprestam dinheiro, ou simplesmente poderiam fazê-lo, jamais devem ter dúvidas quanto à capacidade e ao desejo do Estado de cumprir rigorosa e prioritariamente as obrigações que com eles contraí- 
ram. A cautela na manutenção de altas taxas de juros para os empréstimos públicos que garanta, com alguma folga, que os investidores continuem emprestando ao Estado sobrepuja a eventual necessidade de gastos públicos nas diversas aplicações não-financeiras. Concretamente, isso implica que o Estado, diante da necessidade de arbitrar a alocação de seus recursos entre pagamento e rolagem de sua dívida e políticas públicas, restringe, ou mesmo renuncia, a praticar diversos tipos de política social, de infraestrutura, de saúde ou de segurança pública, mesmo que os efeitos negativos dessas omissões terminem custando muito mais aos cofres públicos do que se as despesas fossem efetuadas no momento adequado. Assim, no mundo regido pelas convenções financeiras, há uma lógica férrea que pode fazer que, por exemplo, a conservação das rodovias seja precária, aumentando muito o risco de acidentes, mesmo se o custo das despesas de saúde e a elevação dos custos de transportes provenientes desses acidentes sejam estimados como muito maiores do que os eventuais custos de conservação ou construção das estradas. O horizonte temporal e a prioridade máxima geralmente aceitos são os do repactuamento da dívida pública. Levando mais adiante essa ideia-força, os ideólogos das finanças propõem (e executam) o Estado mínimo com o caixa vazio. Nessa construção, os mercados financeiros podem exercer permanentemente a sua tutela sobre o Estado, sua burocracia e protagonistas políticos por meio da rolagem contínua da dívida pública. Dessa maneira, os agentes ligados ao Estado, vistos implicitamente, nesse contexto, como ineficientes e potencialmente desonestos, são controlados pelos mercados, que garantem um mínimo de racionalidade para o confuso mundo da burocracia governamental (Guex, 2003).

Continuará prevalecendo o tipo específico de viés, ou de cegueira institucional consagrados pelas habitualidades produzidas nos mercados financeiros? Lembrando um princípio basilar da filosofia analítica (Hacking, 2002), a própria definição do que é a crise atual é dependente da capacidade de o espaço financeiro manter a sua autonomia e impor um sentido favorável para a interpretação da crise. Nesse sentido, é um bom procedimento epistemológico que a sua sociologia não avance uma explicação peremptória para a crise e que, em vez disso, examine justamente as linhas de força, as estratégias de manutenção da autonomia financeira e as formas como elas se compõem ou são desafiadas na sociedade. Feita a ressalva, teremos alguma mudança dessa convenção cognitiva num contexto no qual ganha espaço a ideia de que gastos públicos em infraestrutura são excelentes medidas para atenu- 
ar a crise? À primeira vista, o bom senso diz que "sim". Mas é conveniente se ter em conta que, às vezes, as habitualidades mentais se mantêm vivas muito tempo depois que deixaram de "fazer sentido" ${ }^{3}$. É o acaso que responde a essa pergunta? Ou será que a sociologia pode nos ajudar a estabelecer as linhas de força para estimarmos as probabilidades de tipos de resposta?

\section{O CAMPO FINANCEIRO}

Creio que a resposta a essas questões pode ser extraída das circunstâncias em torno da formação do campo financeiro (Bourdieu, Heilbröm e Reynaud, 2003). Temos, diante de nós, a versão brasileira de uma configuração social que tomou forma nos últimos anos em muitas sociedades desenvolvidas ou em desenvolvimento. Para entendermos a lógica e a força dessa construção social, precisamos construir, inicialmente, um ponto contra-intuitivo, segundo o qual o campo financeiro engloba e dá sentido para a ação e forma as sensibilidades de vastas parcelas das elites nacionais, indo bem além dos financistas propriamente ditos (Grün, 2005b). A análise da gênese e desenvolvimento das chamadas "ferramentas financeiras estratégicas" - aquelas que transformam significativamente o espaço organizacional em que são aplicadas - especialmente a governança corporativa - abrem a janela desse jogo intricado e nada óbvio de competição e cooperação entre os diversos setores das elites, que desemboca nas inovações financeiras. Elas são, também, inovações sociais, que, uma vez postas a funcionar, servirão de plataforma para alterações importantes nos habitus e nas formas de sociabilidade vigentes no espaço que estudamos (Grün, 2005b). E mais do que isso, quando analisamos os paralelismos e divergências entre o engendramento da governança corporativa e outra grande inovação financeira que são os fundos de private equities, observamos a construção de uma cultura e de um quadro moral internos ao mundo das finanças que irão se espraiar bem além dos mercados financeiros propriamente ditos. Neles, a governança corporativa ganha um sinal positivo de novidade benfazeja, que deve ser celebrada e incentivada pela sociedade e pelo Estado, enquanto os fundos de private equities recebem o sinal negativo de desenvolvimento perverso do mundo financeiro, que deve ser controlado por causa de seus desdobramentos antissociais (Joseph e Ocasio, 2005; Williams e Froud, 2007; Grün, 2009b).

Uma armadilha atrapalha e facilmente conduz à obliteração da análise sociológica que pretende reconstituir a lógica de funcionamento e dinâmica de espaços como o nosso campo financeiro: é a pressuposição 
espontânea de que o seu principal produto é simplesmente a produção de riqueza material, ou a sua transferência de uns para outros. Para entender esse espaço precisamos reforçar outro ponto teórico pouco intuitivo: como quaisquer outros campos, o financeiro, antes de qualquer coisa, e prioritariamente, produz sentido. É esse sentido que permite a acumulação de riquezas e confere legitimidade e, portanto, estabilidade, para os ganhos econômicos. E, finalmente, a identificação do campo financeiro com o campo do poder é uma boa medida da capacidade de fazer espraiar esse sentido ali produzido pela sociedade e assim produzir a hegemonia das finanças, da qual a opulência dos financistas é uma consequência, e não a causa ${ }^{4}$.

Mas como se produz esse sentido? Não é evidente que nossos financistas sejam produtores culturais, tampouco que suas vidas sejam vistas como epopéias dignas de serem glorificadas pelos profissionais da mídia e seguidas pelo resto da população. Muito menos que a intricada engenharia financeira que se tornou o fundo de comércio específico dos financistas nos tempos atuais seja vista como o apogeu das realizações científicas ou intelectuais da humanidade ${ }^{5}$. Entretanto, o que está em jogo não é a glamorização direta do espaço, de seus personagens e de seus feitos, mas, antes, a sua capacidade de impor uma maneira de representar a sociedade brasileira, seus problemas, potenciais, e, principalmente a própria definição do que é progresso e de como alcançá-lo. É nesse sentido que se torna interessante acompanhar a história recente daqueles dispositivos criados na esfera financeira e a sua difusão pela sociedade. Eles embutem pressupostos comportamentais que são aqueles da antropologia filosófica que vigora no mundo financeiro. E a partir da aceitação tácita das mudanças comportamentais que se dão quando os dispositivos são aceitos, diversos setores da sociedade vão sendo colonizados cognitivamente e se acostumando a entender o bom senso da convivência financeira como o senso comum que deve reger a totalidade das relações sociais (Grün, 2009a). E a teoria moderna da metáfora vai nos ajudar a entender como a habitualidade do uso desse enquadramento cognitivo nos predispõe a aceitar as receitas sociais e a pregação política inspirada na cultura dos mercados financeiros (Ortony, 1993; Gigerenzer e Goldstein, 1996; Lakoff, 1996; Douglas e Ney, 1998).

\section{AS FINANÇAS IMITAM A ARTE}

É, aqui, pertinente notar algumas analogias entre o campo financeiro e o campo da arte. No último, para o qual já dispomos de muitos estu- 
dos, o somatório de monografias permite análises mais acuradas e o desenvolvimento mais expressivo da teoria geral dos campos. Vemos, então, um setor tradicional, em geral dominante, que pratica uma arte compromissada com setores bem estabelecidos da sociedade, que lhe reconhece a "qualidade" de quem "realmente" sabe pintar ou escrever, valorizando financeiramente a sua produção. E os praticantes dessa "arte convencional" acabam também construindo a sua legitimidade dessa aceitação e valoração monetária. Esse setor convive de maneira em geral tensa com uma vanguarda que pratica formas experimentais de arte, dificilmente aceitas pela "burguesia" e que, não por acaso, não acata os valores do primeiro grupo já estabelecido, em especial a ligação entre sucesso artístico e econômico. Não por acaso, a ascese é um componente essencial das teodiceias das vanguardas artísticas e a denúncia da "corrupção material" do setor consagrado é outro aspecto sempre presente, bem como a defesa intransigente do postulado da arte pela arte, sem nenhum compromisso com atores externos ao ofício, principalmente os burgueses que pagam caro pelas obras de arte estabelecidas. A denegação do interesse material, a negação do dinheiro como escala de valor é, aqui, um dos valores mais importantes, se não o maior (Bourdieu, 1992; Sapiro, 2003).

Ganhamos inteligibilidade para nosso objeto se considerarmos o campo financeiro como um espelho invertido do campo da arte. O setor estabelecido, o dos grandes bancos comerciais de varejo, também pratica formas de legitimação que compõem com a sociedade inclusiva e talvez a forma específica de responsabilidade social praticada na sociedade brasileira atual pelos grandes bancos seja o melhor reflexo dessa tendência ${ }^{6}$. Aqui, a relação com a vanguarda é homóloga àquela que observamos no espaço da arte. Num primeiro olhar, ela parece simplesmente contrária, já que aqui o dinheiro é o valor supremo e os "vanguardistas" são seus maiores cultuadores. Mas se observarmos mais atentamente, verificaremos que os atores não têm outra escolha se não a de se expressarem na linguagem do dinheiro, a única legítima, enquanto no mundo da arte é exatamente o contrário. Mas quem negará que os artistas têm motivações materiais e, também, que os financistas podem ser levados por pulsões "irracionais"? Se um financista não resiste ao impulso de espionar seus concorrentes, ele irá justificar o custo econômico, tempo e risco dessa atividade na rubrica da necessidade de monitorar o mercado (Lordon, 2002; Grün, 2007a). Se ele aprecia alguma forma de arte, irá "investir" na sua aquisição ou exibição. 
Em suma, ele está condenando a se expressar na fria linguagem do cálculo econômico.

Mas se o constrangimento pesa sobre o campo que analisamos, ele não pode pairar sobre a sociologia que se ocupa dele, sob pena de sucumbir ao fetichismo que lhe é próprio e, pecado capital, não avançar sobre o senso comum. A cronologia da crise no Brasil, ainda que necessariamente parcial - entre outros motivos porque nada pode nos assegurar que ela já tenha mostrado todas as suas facetas no momento em que escrevemos - indica claramente que seus desdobramentos são subordinados às disputas cultural e ideológica que atingiram intensidade inédita desde a ascensão de Lula e, particularmente, depois dos escândalos de 2005.

\section{A GUERRA CULTURAL E SUA CRONOLOGIA RECENTE}

A colonização imposta pela predominância financeira não é, evidentemente, uma via de mão única. Ela convive dinamicamente com outras tendências no seio de um processo de guerra cultural que produz resultantes contingentes que se alteram no tempo e espaço. Trabalho o conceito de "guerra cultural" desde 1999 (ver Grün, 1999). Ele élonginquamente inspirado na ideia de KulturKampf dos debates germânicos do final do XIX e mais próximo intelectualmente da ideia homônima de guerra cultural da sociologia e do cognitivismo norte-americanos recente (Hunter, 1991; Lakoff, 1996; Williams, 1997; Rieder e Steinlight, 2003). A forma atual como eu trabalho o conceito está detalhada em Grün (2005a) e a sua instrumentação direta vem da filosofia analítica de Nelson Goodman (1978; McCormick, 1996) e da reflexão sociológica de Bourdieu, que nela se inspira (Bourdieu, 1997).

Na operacionalização da ideia na crise é possível traçarmos diversas cronologias que marcam as disputas e transações culturais que ocorrem no seio do campo financeiro, e mesmo fora dele, mas impactando o seu funcionamento. Nos limites desse artigo, opto por um sequenciamento "curto", que vai do início de 2003, e do primeiro governo Lula, até meados de 2009, que está mais diretamente ligado a alguns resultados recentes e surpreendentes da crise financeira na cena econômica brasileira. No primeiro momento (t1) temos uma situação de submissão do senso comum ao bom senso produzido nos mercados financeiros, no qual o principal marco é a discussão da PEC (proposta de emenda constitucional) 192, de 2003, a chamada PEC do mercado financeiro, 
ocasião em que o primeiro governo Lula claramente se curvou diante da força cultural daquele bom senso (Leonel e Tavares, 26/3/2003; Grün, 2004). Um segundo momento (t2) pode ser caracterizado quando, diante da ofensiva escandalizadora antigovernamental que começa em 2004, observamos uma oscilação inesperada, na qual a defesa possível do governo começa a alterar as linhas de força culturais prevalecentes, enfraquecendo a doxa econômica (Alencar, 30/10/2006; Grün, 2008a). Um pouco mais adiante, no momento quente das eleições presidenciais de 2006, mais uma oscilação (t3), que representou o aprofundamento da inflexão do quadro imediatamente anterior (Gois, Jungblut e Damé, 6/1/2007; Grün, 2008b).

No texto atual, sustento que a sequência é fortemente explicativa dos desenvolvimentos que se produziram a partir da crise financeira internacional. Diversas mudanças que surpreenderam o ceticismo das esquerdas desencantadas com o pragmatismo do governo e também os analistas de "de bom senso", locutores do senso comum até então prevalecente nos mercados, tiveram a sua semente plantada na sequência de episódios acima e, creio eu, seriam incompreensíveis sem levarmos em conta aquela inflexão que foi produzida antes da crise. É interessante também notar que os economistas e comentaristas ortodoxos, envolvidos cultural e economicamente na manutenção da doxa, e até então ungidos na condição de donos da verdade econômica, sentiram e registraram claramente o golpe anterior, que impactou o debate público daquele momento, e realinhou as linhas de força da disputa simbólica (Sardenberg, 1/11/2006; Lamucci, 24/10/2006).

\section{O INTERNACIONAL E O NACIONAL NA DOMINAÇÃO FINANCEIRA E NA SUA CONTESTAÇÃO}

Em termos internacionais, o produto simbólico mais robusto da produção cultural engendrada pelo campo financeiro funcionando na sua plenitude e sem oposição é o homo œconomicus. Numa primeira impressão, essa figura não passa de uma abstração necessária para a modelação da atividade econômica. Nesta acepção, ela é aceita ou criticada como uma aproximação razoável, ou não, do comportamento dos seres humanos nos momentos em que tomam decisões que têm impacto em sua vida material. O campo financeiro produz uma espécie de feitiçaria, um magnífico exemplo moderno do círculo da crença de Mauss e Lévi-Strauss (1983), que confere vida a esse Golem da modernidade. Nas formas de comportamento incentivadas pelo campo, tanto para 
seus jogadores, quanto para seus clientes, o exemplo do homo ceconomicus deixa de ser aquela simples abstração que interessa apenas aos intelectuais, para se tornar um exemplo das virtudes do "ser humano racional", o único que consegue aproveitar, e que merece, as benesses oferecidas pelo mundo das finanças. Esse modelo ideal de virtude vai se difundindo nos espaços sob a influência do nosso campo, colonizando outras tribos e, quando encontra o espaço desimpedido, ou quando prevalece sobre outras tendências, vai aproximando cada vez mais a figura ideal da realidade (Garcia, 1986; Douglas e Ney, 1998; Bourdieu, 2000; MacKenzie, 2006).

Especificamente, podemos dar conta do fenômeno da dominação financeira que impera sobre a sociedade brasileira mostrando como ele se realiza por meio da atração de diversos segmentos importantes das suas elites para dentro do circuito dos mercados ${ }^{7}$. Talvez o alcance e os mecanismos pelos quais essa integração esteja se efetivando não sejam muito claros, pois eles são denunciados na disputa política, e realmente se assemelham a fenômenos já tradicionalmente descritos pela literatura. Mas, sustento eu, as diferenças também são importantes, e particularmente para a análise do campo financeiro e da crise recente. $\mathrm{Na}$ esfera política, ela é a forma atual de realização do alongamento dos circuitos do poder e de sua legitimação no atual estágio do capitalismo internacional (Bourdieu, 1989). Esse processo é menos evidente e é facilmente confundido com a simples cooptação, descrita pela teoria clássica das elites. Entretanto, o seu resultado não é só a incorporação de novos grupos no campo do poder, mas também de diversos interesses e sensibilidades dos recém-chegados, e a principal consequência dessa especificação, que dificilmente poderia ser negligenciada pela análise sociológica, é a alteração e sofisticação do modo de dominação prevalecente (Bourdieu, 1976; Grün, 2009b). Trata-se, não por acaso, de um fenômeno sobre o qual a sociologia contemporânea tem se debruçado com frequência, e que recebe diversos tratamentos, tributários das diversas tradições, mas convergentes no ponto que nos interessa no momento. Na linguagem da vertente neofuncionalista da sociologia alemã contemporânea, estamos diante da complexificação da sociedade e, em especial, das suas esferas política e ideológica (Bohn, 2006). Na versão da teoria do diálogo de Boltanski e Chiapello (1999), o capitalismo realiza a "incorporação da crítica" e se torna mais robusto e sofisticado. 
Um exemplo central da vitalidade desse capitalismo "tardio" está justamente no desenvolvimento da governança corporativa. De início, ela era um conjunto de dispositivos engendrados no mercado financeiro, destinados a fortalecer as posições dos acionistas minoritários das empresas diante de seus administradores ou dos acionistas majoritários. Nesse sentido, ela já ensaiava alguma polissemia, pois atraía os diversos operadores de fundos de pensão oriundos do movimento sindical, e esses flexionavam o sentido original, conferindo uma dimensão política e moral mais ampla à "democracia dos acionistas", que ultrapassa a intenção original de tornar o mercado de capitais atraente para pequenos investidores e passa a ser uma cruzada pela "domesticação do capitalismo selvagem" (Jardim, 2007). Posteriormente, ela alarga ainda mais o seu espectro, acrescentando as questões de responsabilidade social e sustentabilidade ambiental. Nessa segunda interação, ela instala os "balanços sociais", discute o "Índice de Sustentabilidade Empresarial" e, por esse caminho, ela incorpora os líderes de ONGs sociais e ambientais, que serão os fiadores e, muitas vezes, também os operadores das novidades. E nessa nova configuração, muitas das preocupações e críticas formuladas por esse grupo de agentes são traduzidas e incorporadas ao mundo empresarial (Grün, 2005b); Sartore, 2006).

Ao incorporar as demandas sociais e ambientais por meio de alguns dos seus porta-vozes, a ordem financeira perde a rigidez que muitos lhe atribuem, mas ganha força em dois planos: 1) privando os setores que normalmente se opõem a ela de seus porta-vozes já reconhecidos; 2) incorporando parte de suas demandas e, assim, diminuindo o possível clamor antifinanceiro da população em geral. É claro que nem tudo "são rosas" no caminho das implantação da governança corporativa no Brasil. Os solavancos desse trajeto são percebidos mediante o acompanhamento da guerra cultural que enunciei acima. A análise da polissemia social que é produzida, ampliando e alterando o significado da governança corporativa e demais instrumentos financeiros, podem ser explorados para mostrar as fissuras, limites e especificidade da dominação financeira que incide sobre a sociedade brasileira (Grün, 2009b). Mas, de início, é mais importante deixar clara a "força cultural" dos dispositivos financeiros, que produzem e reforçam as convenções cognitivas que dão consistência à dominação. Se há uma maneira de "fazer coisas com palavras" (Austin, 1962) na sociedade, na economia e na esfera política, estamos diante dela. 


\section{OS DESAFIOS À AUTONOMIA DO CAMPO}

Quando a crise financeira internacional passou a ser manchete obrigatória na imprensa brasileira, a primeira caracterização, tributária da guerra cultural interna e da tentativa de manter a autonomia do espaço, foi a de criticar e ridicularizar o diagnóstico do presidente Lula, em especial sua frase dizendo que seus efeitos sobre a economia nacional não passariam de umas "marolinhas", que foi repercutido à exaustão (Galhardo, 4/10/2008). Afinal, a crise se anunciava internacional e gigantesca, e dizer que o Brasil poderia ser poupado só poderia revelar uma profunda incompreensão da economia mundial.

Um pouco mais tarde, fomos informados de outras provas inequívocas da baixa compreensão de Lula sobre a situação. Talvez a mais expressiva tenha sido a crítica ao seu comentário sobre a crise ter sido provocada por "gente loira de olhos azuis" (Godoy e Iglesias, 27/3/2009). Outro episódio marcante ocorreu em torno da divulgação de prejuízos substanciais de algumas grandes firmas nacionais com derivativos cambiais, causados pelas alterações súbitas nos valores relativos das moedas nacionais que a crise provocou, desvalorizando a moeda brasileira depois de um período longo de valorização em relação ao dólar. Os responsáveis financeiros das empresas apostavam na continuidade da valorização da moeda brasileira, mas a crise recolocou o papel de "refúgio de valor em última instância" da moeda norte-americana, desvalorizando subitamente o Real. E nesse momento aparece mais uma rodada de críticas, dessa vez à sua reprimenda aos empresários que perderam nas posições com derivativos cambiais (Ninio, $22 / 5 / 2009$ ). Essa sequência de críticas reforça a pretendida visão rústica que Lula teria da cena financeira internacional e mostraria que os desafios mais recentes ao bom senso financeiro perpetrados por diversos membros do governo federal não passariam de aventuras irresponsáveis.

No âmbito mais interno do campo financeiro, corroborando o argumento da sua forma seminal de legitimidade, as perdas das empresas com os papéis cambiais foram atribuídas à falta de boa governança corporativa. A ação individual independente ou desimpedida de alguns executivos financeiros que agiram sem consultar os acionistas teria causado o problema. Os financistas das empresas teriam assumido mais riscos do que poderiam, e os acionistas não teriam sido devidamente informados dos níveis de exposição cambial/financeira em que as em- 
presas estavam incorrendo. Assim, se a governança corporativa estivesse funcionando como se deve e espera, tais passos comprometedores não ocorreriam e as empresas teriam evitado os grandes percalços a que posteriormente foram obrigadas a fazer frente (e não "à ganância dos empresários" que teria, segundo Lula, causado as dificuldades (Ninio, 14/10/2008;22/5/2009). É claro que não nos interessa discutir substantivamente a justeza desses diagnósticos e julgamentos, mas, sim, a invocação da "boa governança corporativa" como critério de conduta empresarial legítima no período em que estamos atravessando. Isto sem falar no corolário da ridicularização da posição de Lula, que não convergia integralmente com a crença engendrada no campo.

As dificuldades mais expressivas foram anunciadas pelo grupo Votorantim, pela empresa Aracruz Celulose e pela empresa agroindustrial Sadia, todos gigantes industriais de reputação consagrada, e muito se especulou sobre outras empresas que teriam enveredado pelo mesmo caminho (Valor Online, 10/10/2008; Vieira, 11/2/2009; Ribeiro, 12/1/2009; Onaga, 16/10/2008; Tereza, 26/11/2008; Friedlander e Grinbaum, 30/11/2008). Nas três empresas, operações financeiras malsucedidas por causa da súbita reversão de expectativas puseram em xeque a solidez tradicional dos negócios (Barbosa, 11/10/2008; Vieira, 27/11/2008a). E o "erro" apontado, aceito pelos seus porta-vozes e largamente divulgado na mídia, foi a falta de boa governança corporativa das empresas (Salles, 20/1/2009; Vieira, 21/1/2009; Vieira, $27 / 11 / 2008 b)$. Dificilmente encontraríamos manifestações mais expressivas e evidentes da impregnação desse dispositivo financeiro no espaço das discussões econômicas e, portanto, na cultura econômica brasileira recente ${ }^{8}$.

\section{0 "CONSELHO DOS ANCIÃOS"}

No mesmo período, deparamos com artigos e manifestações públicas de alguns atores importantes no debate econômico que no passado recente se notabilizaram por criticar os excessos da "financeirização". Dentre eles, registremos Antonio Delfim Neto, no âmbito nacional, e, na esfera internacional, Georges Soros, que é muito traduzido e comentado no Brasil. Delfim consegue a legitimação inédita de ser simultaneamente colunista semanal de publicações importantes que representam pontos divergentes, e mesmo opostos, do espectro ideológico, como Valor Econômico, Folha de S. Paulo e Carta Capital. No âmbito internacional, vemos Soros colunista ao mesmo tempo da New York Review 
of Books e do Financial Times, profusamente citado no Le Monde - o cotidiano que é registrado pela sociologia como o mais próximo representante do consenso entre as elites francesas, além de ser considerado uma das "estrelas" do Fórum Econômico de Davos. No Brasil, verificamos que Soros publicou três colunas na Folha de S. Paulo, em 2009, e foi citado oito vezes no Valor Econômico apenas no mês de dezembro de 2009. Em notável sintonia, eles lembram que a crise financeira não pode servir de pretexto para reações generalizadas contra o uso dos instrumentos financeiros ou seus usuários, em especial, o fantasma do excesso de regulamentação que tolhe a criatividade dos financistas.

De início, é necessário deixar claro o "caso de amor eterno" entre os financistas e os economistas, que talvez se abale em momentos de crise aguda, como as economias que neles entraram a partir de outubro de 2008, mas que tende a se recompor. Há uma razão especificamente analítica que provoca a aproximação. Para os últimos, os primeiros seriam os agentes "práticos", encarregados de pensar e executar a tão sonhada alocação ótima de recursos econômicos que, por sua vez, iria gerar a maior riqueza possível a partir da base material existente na sociedade. Assim, em princípio, os financistas são agentes benfazejos e sua ganância ou cupidez são enquadrados na chave "vícios privados, virtudes públicas". Ainda que, aos olhos dos leigos, os valores absolutos das rendas auferidas pelos financistas possam ser considerados "obscenos", o automatismo do economista é considerar essa despesa como um custo social razoável para se atingir a finalidade da alocação ótima de recursos econômicos. E o corolário dessa postulação diz que aqueles que apenas criticam os financistas, sem reconhecer sua contribuição para o bem-estar econômico e social, são os nostálgicos de tempos arcaicos, quando a sociedade era estagnada e conservadora.

Vamos, então, aos "mestres". Diz Delfim (Oliveira, 5/10/2008):

[As crises] nunca têm as mesmas causas, porque a teoria econômica ajuda na construção de instituições que previnem a sua repetição. Mas o fato é que a superação de uma delas já traz em si o germe da próxima. A última, fortíssima (1979/83), foi supostamente causada pelo "excesso de regulamentação"; a atual é, aparentemente, produto da "falta de regulamentação" [...]. O pêndulo vai para o outro lado, agora. Eles estão propondo restabelecer a regulação. O drama é o seguinte: aquela desregulamentação produziu resultados extremamente positivos e terminou numa desgraça. Não se pode jogar fora a criança junto com a água do banho. É claro que é preciso regular, mas é preciso manter a iniciati- 
va, a capacidade que o sistema tem de inventar coisas novas e, ao mesmo tempo, impedir que ele repita os erros. Vamos entrar num período que levará uns dois ou três anos de correção dos erros. Vamos moer tudo isso.

E George Soros, por sua vez:

Dadas as tremendas perdas sofridas pelo povo em geral, há um perigo concreto de que a desregulação excessiva acabe virando uma re-regulamentação punitiva. Isso seria lamentável porque devemos considerar que as regulações são piores do que os mecanismos de mercado. Como eu tenho sugerido, os reguladores não só são humanos, mas também são burocráticos e suscetíveis à corrupção. Seria, portanto, desejável que as reformas aqui delineadas possam evitar uma regulação excessiva. (Soros, 2008)

Notemos a sintonia entre as postulações dos dois atores, que contribui para revelar a mecânica social engendrada pela configuração que chamamos de campo financeiro. O primeiro, na esfera nacional; o segundo, na internacional, ambos vistos atualmente como consciências críticas do mundo econômico, depois de um período anterior em que foram, cada um no seu âmbito, considerados a expressão mesma da rapacidade ou do cinismo econômicos. A notável coincidência de posicionamento pode ensejar diversas análises sociológicas. Aqui, registremos simplesmente que o capital simbólico dos atores é posto para trabalhar e, assim, engendrar um produto preciosíssimo no período em que entramos: a contenção dos estragos produzidos pela crise na legitimação da ordem financeira em uma escala que não ameace a prevalência das finanças na sociedade.

O que leva esses agentes a, nesse momento delicado, emprestarem a sua legitimidade e avocarem a defesa do mundo financeiro diante do ambiente claramente hostil? O ponto é que, na linguagem de Goodman (1978; cf. Bourdieu, 1997), o campo financeiro constroi um mundo em que vale a pena viver. Para isso ele engendra uma libido específica que impele seus participantes a tomarem posição em sua defesa, mesmo aqueles que têm a vida já completamente estabilizada. E esse fato nos ajuda a aceitar que há um combustível menos evidente impulsionando os agentes, e que é ainda mais poderoso que o dinheiro.

As formas e conteúdos que a defesa assume irão variar com as posições dos agentes naquele espaço, mas serão compreensíveis quando levar- 
mos em conta os constrangimentos que a configuração exerce sobre seus participantes. Iremos assistir a uma interessante e funcional divisão do trabalho de dominação. À primeira vista, essa "orquestração sem maestro" pode parecer o enredo de uma daquelas conspirações dos poderosos que nos acostumamos a ler e ver. E toda uma vasta e diversificada literatura sobre golpes e cabalas espetaculares acaba fornecendo quadros de referência para pensarmos a situação a partir dessa chave (Weber, 1999; Taguieff, 2005). No Brasil, a presença constante do financista Daniel Dantas nos noticiários econômico, político e policial dá forma local a essa tendência internacional (Grün, 2008a). Mas, pretendo demonstrar, essa situação é explicada pelos movimentos e percepções engendrados pelo campo e bem além das possibilidades de manipulação e controle de algum agente ou grupo particular. E é esse mecanismo, formado de um conjunto automático de ações e reações engendradas pela sociabilidade contemporânea, que confere a enorme resistência que as finanças mantêm na sociedade, contrastando com o esperado e intuitivo enfraquecimento dos seus agentes e ponderações.

\section{O FANTASMA DO COMUNISMO}

A intuição fala, e não por acaso, que a crise econômica fez crescer as esperanças dos indivíduos e grupos que se incomodam com a proeminência que as finanças ganharam na cena econômica e política das últimas décadas. Uma vez que ela foi deflagrada pelos mercados financeiros, parece que ela põe em questão os mecanismos de governança econômica e social que esses últimos delinearam ou apoiaram. Evidentemente que esse desfecho é possível, mesmo se a análise sociológica do espaço das finanças aponta que ele não é muito provável. Sem se fiar nas salvaguardas da sociologia, os financistas pressentem um perigo, real ou imaginário, e reagem a ele. E aí, no espaço nacional, vemos a ação, entre outros, de Gustavo Franco (1/11 / 2008) e Dionísio Dias Carneiro $(2 / 11 / 2008)$, dois economistas/financistas do núcleo duro do pensamento dominante, oriundos do Curso de Economia da Pontifícia Universidade Católica do Rio de Janeiro (PUC-Rio). E o fantasma do comunismo acaba despertando, sob o curioso estímulo cruzado dos defensores mais ferozes da ordem financeira precedente e dos seus críticos mais acerbos (Zeleny, 7/3/2009; Heffer, 9/10/2008).

O despertar do velho fantasma não é apenas uma curiosidade dos tempos da crise. O espectro do comunismo, em parte provocado, ou justificado, pela crítica esquerdista mais aguda é utilizado nas disputas eco- 
nômicas centrais da crise, que dizem respeito à socialização dos prejuízos do sistema financeiro e à apropriação dos eventuais lucros produzidos nas operações de salvamento e nos momentos posteriores a elas. Como devem ser contabilizados os enormes montantes disponibilizados pelos governos aos agentes financeiros? Como aporte de capital? Como aquisição dos chamados "ativos podres", ou "ativos tóxicos"? Como uma injeção provisória, contabilizada à parte para não diluir o valor das ações e o patrimônio dos acionistas originais das organizações? Como ficam as remunerações dos dirigentes das organizações que foram ou serão socorridas pelo Estado? E as remunerações anteriores? Deverão ser devolvidas? Enormes transferências de renda serão realizadas num sentido ou noutro, dependendo de quais critérios prevalecerem. Mesmo os mais fervorosos crentes da racionalidade econômica terão de admitir que estamos na era da "contabilidade política". E o fantasma do comunismo é uma peça fundamental nas tentativas de "passar o mico" - essa expressão que tem origem no jogo infantil e que os financistas usam muito quando se trata de repassar os prejuízos de sua ação. A acusação de "comunismo" para a ação pública previne formas de contabilização que desfavorecem os financistas originais. Nesse contexto, a ideia de objetividade econômica se mostra uma fantasia distante. Mesmo para os céticos, a crise revela que a "racionalidade econômica" é um produto intelectual engendrado pelas disputas sociais e se altera no mesmo sentido que suas linhas de força, produzindo enquadramentos cognitivos específicos, que nos conduzem a conferir racionalidade a determinadas proposições e condutas, e a refutar outras (Fleck, 1979; Hacking, 2002; Daston e Galison, 2007). E uma das maiores manifestações de força da dominação é a de conferir a verossimilhança de racionalidade para os produtos atuais do campo financeiro (Lordon, 2008). Concretamente, isto significa induzir a sociedade a esquecer de cobrar dos agentes financeiros os prejuízos coletivos provocados pela derrocada de diversos grupos e esquemas.

Em termos internacionais, a complexidade da relação entre o sistema político e o campo financeiro fica bem evidenciada na situação atual: as agora famosas hipotecas subprime (de risco \& juros altos e mensalidade variável) foram a solução encontrada para financiar a casa própria de parcelas da população que anteriormente estavam distantes deste tipo de aquisição (Becker, 20/12/2008; Fligstein, 2009). Desde o programa para o primeiro governo Thatcher, possibilitar essa aquisição foi um dos pilares da estratégia neoliberal anglo-americana de tornar aqueles países "nações de proprietários" e, assim, induzir os cidadãos/eleito- 
res de meios mais modestos a mudarem definitivamente a sua identidade de trabalhadores para a de proprietários (Conservative Party, 4/10/1976). Pode assim haver interesse político na rotulação, mas é factualmente incorreto e uma temeridade intelectual dizer que as subprimes, consideradas o deflagrador imediato da crise, são simplesmente o produto da ganância dos financistas. Mais recentemente, também ficamos sabendo que as situações financeiramente delicadas da Grécia e da Itália, que provocaram sérios solavancos nos mercados internacionais em fevereiro de 2010, tinham sido, em grande parte, produzidas pela ação conjunta dos governos daqueles países com grandes banqueiros norte-americanos, que os aconselharam a realizar operações financeiras que mascaravam déficits profundos por meio da emissão de papéis lastreados nas receitas futuras dos sistemas de loterias e dos aeroportos (Story, Thomas Jr. e Schwartz, 13/2/2010). Assim, vemos claramente que, como no caso da governança corporativa à brasileira, quaisquer instrumentos financeiros de largo espectro são o resultado de longas cadeias de negociação e de legitimação cruzadas, não só internas à esfera financeira, mas também em outros âmbitos. Reconhecendo essa complexidade, dificilmente poderemos separar a esfera financeira dos outros circuitos de sociabilidade, em especial, o campo do poder. E essa ponderação entre os papéis dos agentes financeiros em senso estrito e outros segmentos das elites separa a análise sociológica da crise de inspiração bourdieusiana daquela "internalista", oferecida pelos Estudos Sociais sobre as Finanças, baseada em circunstâncias internas ao mundo dos financistas e exposta seminalmente em MacKenzie (2009).

\section{OS SOLAVANCOS E A ACELERAÇÃO DAS DISPUTAS NO ESPAÇO FINANCEIRO DO BRASIL}

No espaço situado do Brasil, o primeiro momento da crise foi uma verdadeira "bênção" para os banqueiros tradicionais, que na situação encontraram boas justificativas para avançarem no processo de concentração bancária. Reparemos que os críticos do spread bancário - o principal mecanismo de remuneração dos bancos - apontam justamente a oligopolização do crédito como a causa estrutural e fundamental para explicar o fato de o Brasil ser o "campeão mundial do spread bancário": apresentar a maior diferença entre a remuneração dos investidores que aplicam seus capitais nos bancos e a remuneração dos bancos auferida pelos empréstimos propiciados por esses aportes (Godoy, 1/2/2009; Tereza, 21 /8/2006). É, então, que vimos, no início da crise, a aquisição 
das carteiras de empréstimos dos pequenos bancos pelos bancos maiores com o dinheiro antes imobilizado dos depósitos compulsórios recolhidos no Banco Central (Grinbaum, 7/11/2008; Martello, 26/3/2009). Outro movimento na mesma direção foi o anúncio da fusão entre os bancos Itaú e Unibanco (Valor Online, 3/11/2008), seguida da esperada "resposta" de outros gigantes, como o Banco do Brasil, que se apressou em negociar a aquisição da "Nossa Caixa" (Folha Online, 20/11/2008) e, um pouco mais cedo, a mídia nos fez tomar nota da fusão entre o banco Santander e o banco Real, que estava em banho-maria depois da aquisição da matriz do segundo pela do primeiro (Ribeiro, 24/07/2008). Passaram assim pelos nossos olhos processos ineditamente rápidos e intensos de concentração bancária, que em outros momentos seriam questionados e possivelmente impedidos ${ }^{9}$.

Num lado do tabuleiro montado por essa mesma conjuntura, vemos que os porta-vozes da indústria passam a criticar uma nova elevação do spread bancário e, do outro, o próprio presidente da República alça o tom da crítica contra os bancos a um nível inédito (Alencar, 1/3/2009; Rehder, 13/2/2009). Mas o novo estágio da concentração bancária se instalou e sua reversão não parece estar na ordem do dia, pelo menos enquanto a crise se fizer presente, já que o entendimento prevalecente é que a concentração em torno de poucos bancos muito capitalizados produz a necessária solidez para o sistema financeiro do Brasil. E, diante da crítica à concentração, Roberto Setúbal, presidente do banco Itaú, declara, sem aparente oposição, que "a maioria dos países tem quatro ou cinco bancos de varejo. É normal" (Dezem,12/8/2009).

Numa ação oposta, surgem duas evidências sobre a "ofensiva" do governo federal contra o spread bancário. A primeira foi a substituição do presidente do Banco do Brasil, tido como excessivamente focado na rentabilidade do banco e, portanto, contrário à política desejada (Galvão, 9/4/2009; Ribeiro, 9/4/2009). Mais surpreendente foi o improvável engajamento público do presidente do Banco Central na causa do rebaixamento dos juros, já que sua biografia pregressa de "homem do mercado" o afastaria dessa pregação, tida como "populista" pelo bom-senso financeiro (Rosas, 15/4/2009).

É interessante notar que a postura governamental, mais aguda e sistemática e aparentemente dissonante em relação ao seu comportamento dos seis anos anteriores, visto como conivente com os interesses do mercado financeiro, pode ser considerada uma tentativa de retomada 
de uma tendência inicial. Recuperemos, então, a nossa cronologia, que começa em (T1) com o episódio da malsucedida tentativa de alterar a ordem financeira que o primeiro governo Lula ensaiou logo no seu início (Oliveira, 19/2/2003; Leonel e Tavares, 26/3/2003; Grün, 2004). Aparentemente, diante da falta de apoio para a iniciativa, o governo teria "jogado a toalha" naquele momento, conformando-se com um padrão de convivência com a esfera econômica que preservaria os privilégios que os players têm extraído da economia nacional nas duas últimas décadas (Grün, 2007). Mas, olhando a cronologia da micro-história do período, somos obrigados a ir mais além. Naquele momento apareceu de maneira bastante clara uma sequência iniciada pelas tentativas governamentais de regulamentação, seguida das críticas cada vez mais elevadas e diversas tentativas de acordo sugeridas pelo governo, que, na verdade, eram episódios de capitulação parcial (Oliveira, 19/2/2003; Leonel e Tavares, 26/3/2003). E esse tango foi sendo dançado num pano de fundo caracterizado pelo estado a parentemente catatônico dos possíveis apoiadores do governo, imobilizados diante da violência simbólica perpetrada pelos críticos ligados ao mercado financeiro. Naquele episódio, as linhas de força da disputa cultural fizeram a sociedade enxergar as tentativas governamentais como a simples tentativa de "tabelar os juros" - fazer valer a Lei da Usura (Decreto no 22.626 de 7 / 4/1933), que existe não regulamentada desde a década de 1930, pretensão "jurássica", descabida, regressista e reveladora de um pensamento econômico medieval, segundo os comentaristas, financistas e economistas midiáticos. E também podemos registrar, naquela ocasião, um ótimo exemplo da capacidade de imposição das representações surgidas no campo financeiro sobre o resto da sociedade e, assim, a pouco intuitiva produção de sentido que ele produz, no "duplo sentido" de significação propriamente dita, e de um enquadramento da situação que favorece a atividade financeira (Grün, 2004).

\section{O FANTASMA DO COMUNISMO: VERSÃO BRASILEIRA}

Retornando ao episódio mais recente da troca de comando do Banco do Brasil, já no nosso momento (T3), a primeira reação do "mercado" é atacar as pretensões governamentais invocando o fantasma da "ingerência política", que estaria abalando a credibilidade econômica do banco estatal, e do governo como um todo (Camba, 9/4/2009). Aí a dinâmica cultural que subsume as disputas econômicas e políticas mostra sua envergadura. Surge, então, com toda a força, a versão brasileira do fantasma do comunismo. Ela estava apenas sugerida no final de 
2008, mas o episódio da mudança de comando do Banco do Brasil permite que nossos comentaristas retirem esse recurso de sua caixa de ferramentas culturais.

O banco dito estatal, mas tendo acionistas minoritários privados, pode imprimir à sua ação uma lógica menos diretamente entendida como financeira? Há uma lógica financeira de maximização dos ganhos "para o acionista" que é geralmente aceita como correta, no seio da qual o espaço para ações de fomento econômico são muito reduzidas. A rotina da política brasileira nos acostumou a aceitar o atendimento de alguns grupos de pressão, ditos incontornáveis, como os grandes proprietários agrícolas que se beneficiam do crédito rural e, em especial, de condições privilegiadas de refinanciamento de dívidas passadas. Ainda que tal "desvio" não encontre guarida em termos doutrinários, ele é costumeiramente aceito como uma compensação razoável para o fato de que os bancos estatais estão protegidos da falência pela garantia, em última instância, que o governo federal lhes aporta. É claro que cabe uma discussão sobre as causas da tolerância em beneficiar esse grupo específico das elites que são os grandes proprietários rurais, em geral próximos dos principais protagonistas dos partidos políticos mais tradicionais, como pelo menos indicam as revelações saídas dos escândalos periódicos que o tema suscita (Ribeiro, 5/8/2009; Tenório, 19/10/2006). No momento da crise, o governo pede ao Banco uma ação bem mais ampla, que altera as linhas mais gerais das atividades nas esferas da economia, em geral, e financeira, em particular: que ele rebaixe suas taxas de juros nos empréstimos em geral, de maneira a deflagrar uma dinâmica concorrencial que obrigaria os bancos privados a realizarem reduções análogas. Como os bancos estatais manejavam, naquele momento, quase $40 \%$ do total da oferta de crédito, essa solicitação, se cumprida, poderia efetivamente afetar o mercado de dinheiro.

Até o deflagrar da crise, a resposta a essa demanda seria um sonoro $\mathrm{NÃO}$, amplamente apoiado por todos os intermediários culturais que costumam intervir em situações análogas. A sociologia das finanças contemporânea insiste no papel desses intermediários culturais, ou diretamente financeiros, na constituição do espaço social favorável àquela atividade. Esses agentes, que ganharam evidência nos estudos sobre a internacionalização dos diversos espaços sociais, são responsáveis não só pela tradução de conteúdos oriundos de línguas diferentes, mas, também, de linguagens oriundas de espaços profissionais e culturais anteriormente incomunicáveis. Os mais conhecidos são as chama- 
das agências de rating, que avaliam a solidez e o desempenho dos diversos emissores de títulos financeiros a partir de pressupostos que, supostamente, são os da avaliação prudencial que privilegia a solidez dos entes avaliados e, portanto, a minimização das perdas dos investidores (Sinclair, 2005). Mas, além desse grupo que faz a tradução explícita (e, evidentemente, enviesada), há também os consultores empresariais em áreas que vão desde as relações públicas até a governança corporativa, que circulam tanto entre diversos ramos econômicos como nos países, e o enorme contingente de comentaristas oriundos das academias e da mídia ${ }^{10}$. Até o deflagrar da crise, eles exerciam um papel muito forte de ventríloquos da razão financeira. Não por acaso, um dos maiores contenciosos do momento diz respeito à continuidade ou ruptura desse posicionamento e ação (Lordon, 2008).

É interessante notar que a crise diminuiu a eficiência das "ações práticas" dos intermediários. Em tempos pré-crise, assistiríamos a uma sequência já conhecida. Nela, os economistas e comentaristas econômicos ridicularizariam as pretensões do governo, que seria caracterizada como jurássica e resquício do negro passado socialista do Partido dos Trabalhadores; surgiriam boatos de que o rating do banco iria se degradar e, finalmente, a própria burocracia interna dos bancos se identificaria com o bom senso profissional dos financistas, derrubando a pretensão do governo federal na ponta final do processo, onde ele deveria ser viabilizado. E, num primeiro momento, a presidência do banco manteve a postura esperada. Deviam prevalecer os interesses dos acionistas e o ganho do governo relativo à propriedade majoritária das ações do Banco corresponde fundamentalmente aos dividendos que sua atividade gera ou a venda de suas ações.

Mas, e no novo panorama que tem a crise financeira internacional como pano de fundo? Os exemplos do "Primeiro Mundo" que até agora forneciam os scripts de atuação "racional", parecem ter perdido o encanto costumeiro. Isso significa que a violência simbólica tradicional perdeu um pouco da sua eficácia. Não foi, então, surpreendente anotar que nesse momento se reforçam as argumentações "genuinamente nacionais". A tese da insegurança jurisdicional é recuperada com toda a força, e assistimos a uma reiteração de seu enunciado e, principalmente, da ênfase nos indícios que ajudam a lhe conferir verossimilhança e na tentativa de controlar as fontes de informação sobre o tema. Já que a "inadimplência" é considerada como o principal componente do custo dos empréstimos, não é por acaso que se explicita, nesse momento, 
uma disputa em torno do controle das informações sobre a qualidade do crédito bancário, em especial sobre quem são os "bons pagadores" (Estado Online, 2/2/2009). Rapidamente se forma um contencioso sobre o famoso "cadastro dos bons pagadores". Ele deveria ser operado pelo governo federal ou por um consórcio formado pelos bancos e suas associações patronais (Iglesias e D'Amorim, 22/7/2009)?

\section{OS EFEITOS PERVERSOS}

No momento delicado para a legitimidade do sistema, aparece uma variante apropriada da tradicional retórica dos "efeitos perversos da ação governamental voluntarista" descritos por Hirschman (1991). Em que pese a sua boa vontade e a necessidade social reconhecida, de o preço do dinheiro baixar no país, em especial nesse período de crise, "[...] se o governo insistir com essa medida antinatural de tentar forçar os juros para baixo, apenas criará uma ainda maior escassez de crédito" (Sciarretta, 18/4/2009).

Mais adiante, quando a pressão governamental se intensifica e a magia tradicional se mostra cada vez menos eficiente, o setor financeiro deu mostras - depois soubemos, provisórias - de se conformar com a situação simbólica. Ainda que o spread tenha se mantido, parece que começamos a entrar numa nova situação em que essa forma básica de remuneração da intermediação bancária terá que se inclinar para baixo (Safatle, 3/7/2009; Iglesias e D' Amorim, 22/7/2009).

O conformismo não durou. Em seguida, aparece outra série de atores, os "grandes homens do mercado" do momento e reconhecidos na sociedade. Primeiro, Armínio Fraga, uma espécie de herói dos jovens financistas, agora investido na condição de Presidente do conselho da nova entidade que reúne a Bolsa de Valores e sua homóloga de Mercadorias \& Futuros, para cobrar do governo federal que ele "desmame o mercado", diminuindo as atividades comerciais do Banco Nacional de Desenvolvimento Econômico e Social (BNDES), que balizam e limitam as taxas de juros para empréstimos de prazo mais longo (Moura e Rosas, 07/08/2009). E, logo em seguida, o presidente do banco Itaú, outra voz considerada moderada, e porta-voz das elites tradicionais, vem completar a homilia, lembrando-nos de que "a redução do spread de bancos públicos não é sustentável” (Leopoldo, 12/8/2009).

Mas, no mesmo dia, eis que também ficamos sabendo de outros dados. O primeiro é que o setor bancário como um todo não chega a estar des- 
contente com a atuação governamental, já que, por exemplo, aparece a revelação que os bancos médios "de varejo" estão satisfeitos, pois o governo federal alterou as regras para a outorga de crédito consignado, de maneira a ampliar essa carteira de crédito, fonte de lucro praticamente garantido para o setor (Carvalho, 12/8/2009; Moreira, $12 / 8 / 2009)$. O segundo é que o mesmo BNDES prepara um "fundo garantidor de investimentos", que diminui o risco que os bancos incorrem quando emprestam para os pequenos empresários, substituindo as tradicionais taxas astronômicas por valores mais alinhados com as médias internacionais (Romero, 12/8/2009). O terceiro, que diante de outra manobra dessa aparente ofensiva governamental contra o spread, a tentativa de diminuir as taxas diretas que os bancos cobram pelos serviços que prestam aos clientes, esses últimos estavam recorrendo ao seu anteparo mais tradicional, o Partido Democratas (DEM), ex-Partido da Frente Liberal (PFL) (Ulhôa, 12/8/2009).

E, por fim, outra subsérie de movimentos pouco previsível: depois de uma defesa veemente da ação financeira governamental pelo presidente do BNDES, no dia seguinte à declaração de Setubal, o ministro da Fazenda contradiz diretamente o presidente do Itaú na questão central do spread bancário: "BB vai pressionar e fazer bancos privados 'comerem poeira', diz Mantega" (Ciarelli, 6/8/2009; Cucolo, 13/8/2009; Camarotto, 20/8/2009).

\section{COM QUEM FICA 0 MICO?}

O jogo da legitimação fica incompreensível se não nos lembrarmos da cronologia dos últimos anos, mostrando que não é só da fria lógica econômica que se nutre a imagem positiva dos grandes bancos. Se recuarmos para momentos anteriores do campo, verificamos que os grandes bancos comerciais de varejo, representando o polo dominante do espaço, se caracterizam por terem adotado formas densas de legitimação diante da sociedade, que lhes permite "manter a moral" - utilizar o capital simbólico acumulado - mesmo nesses tempos que se mostram muito difíceis para seus correspondentes do "Primeiro Mundo". Olhando o campo financeiro em "condições normais de temperatura e pressão", vemos que esses bancos investiram maciçamente, nos últimos anos, em atividades de responsabilidade social e de sustentabilidade, que de alguma forma compensavam o clamor deflagrado pelas críticas ao spread bancário "mais elevado do mundo". Essas ações, nas mais diversas zonas do trabalho social e preocupações ecológicas, ca- 
racterizam-se por serem consensuais em termos das suas conotações morais. Assim, os bancos acabam sendo lembrados por diversos setores da sociedade, em especial pelos operadores das boas causas sociais e ambientais por eles patrocinados, como entidades bem situadas moralmente (Grün, 2005b; Sartore, 2006; Grün, 2007a ). E, na esfera pública brasileira da primeira década do século XXI, quando a escandalização sistemática conduz os políticos profissionais e seus mecanismos de decisão a sofrerem um contínuo processo de deslegitimação, os membros das ONGs se transformam em arautos e garantidores, em última instância, da moral e bons costumes. Dessa maneira, nesse momento de perigo para a sua legitimidade, obter a simpatia, ou, pelo menos, o silêncio dos operadores reconhecidos das boas causas sociais, cívicas e ambientais, é um grande trunfo.

Do seu lado, os "jovens financistas" apresentavam mecanismos de legitimação diferentes. Eles se definem como inovadores no espaço, que trazem soluções para problemas econômicos, como a viabilização dos consórcios que disputaram a privatização das empresas estatais nos anos 1990, fundos de recebíveis, que formalizaram e expandiram o crédito popular via cheques pré-datados e a mais recente expansão da produção de etanol mediante instalação de novas usinas, usando fundos de private equity (Mundo Neto, 2008). Ainda que a pesquisa de campo (Grün, 2005b) mostre uma enorme interação desses "inovadores" com os bancos tradicionais, que se beneficiam das novidades adotando-as assim que elas se mostram viáveis, e sem correr os riscos da inovação - as críticas contra a "financerização" acabam recaindo sobre nosso polo inovador, que também acaba sendo o principal prejudicado pelo súbito arrefecimento do fluxo de recursos financeiros para as suas atividades de "vanguarda", que, no novo contexto, perdem o rótulo de "inovadoras" e passam a ser caracterizadas como "aventureiras", ou, no mínimo, como "arriscadas"11.

A caracterização internacional prevalecente reza que a crise foi deflagrada pelos excessos de "criatividade" do setor financeiro (Wolf, 15/4/2009; Lordon, 2008). Logo, seus culpados já estão designados e são justamente os "inovadores" do campo financeiro. Ainda que o segmento brasileiro desse grupo internacional seja apenas um "player" pouco expressivo no jogo, mais "tropicalizando" inovações concebidas no mundo anglo-saxão do que propriamente as inventando, algumas repercussões diretas apareceram ${ }^{12}$. A primeira delas, já referidas, foram as perdas expressivas com derivativos cambiais que algumas empresas exportadoras declararam logo no início da crise, atribuin- 
do-as à má gestão de seus executivos financeiros. Em seguida, os boatos sobre a exposição de afortunados brasileiros na famigerada pirâmide de Bernard Madoff, a partir de investimentos que teriam sido aconselhados pelos financistas nacionais. Em ambos os casos, uma primeira bateria de notícias atribuía essas operações malsucedidas aos conselhos e apoio organizacional dos grandes bancos. Mas elas foram rapidamente estancadas e substituídas por outra versão, que imputava os erros a banqueiros menos estabelecidos, que operavam em escala mais reduzida e que, no subespaço social que investigamos, se situam no polo inovador (agora aventureiro) do campo financeiro (Cançado e Modé, 18/12/2008; Monteiro, 20/2/2009). Assim, ainda que a situação brasileira se distinga bastante daquela observada nos países centrais, a predisposição de caracterizar um tipo bem definido de culpado no polo sociologicamente mais jovem do espaço - aquele que automaticamente consideramos impetuoso e aventureiro - também se observa por aqui ${ }^{13}$.

A resultante dessa configuração é que o processo de concentração bancário, que normalmente é combatido porque torna mais fácil o controle do fluxo de recursos econômicos da sociedade por um número cada vez menor de banqueiros, que assim ganham força para arbitrar os juros de acordo com a sua conveniência, acaba se justificando como medida "excepcional" no contexto da crise. E observamos então que, na esfera das retóricas, prevalece aquela que reza as virtudes da "economia de escala" na atividade financeira, que torna os bancos mais seguros pelo volume de recursos que poderiam mobilizar diante de alguma situação adversa, contra a visão alternativa que tenta acautelar a sociedade contra a "oligopolização do crédito", que chama a atenção para as assimetrias entre ofertantes e tomadores de crédito. É interessante que a crise deflagrou o debate sobre o moral hazard - a necessidade de evitar que as instituições financeiras sejam grandes demais para falirem e esse debate praticamente não se faz no Brasil (Chan, 2/2/2010; Saddi, 23/12/2009). Mas outro efeito previsível do regime de verdade produzido pelo campo financeiro e difundido através da sociedade é a pouca ressonância daquela advertência.

\section{FLEXÕES SEMÂNTICAS E FORMAS DE ARGUMENTAÇÃO}

O argumento da "economia de escala" apresenta nuanças que revelam muito das formas de legitimação e, consequentemente, dos desfechos mais prováveis para a crise. Primeiramente, ele é invocado num momento que por diversos motivos é pouco favorável ao mundo financei- 
ro e às suas causas. A ideia de se conseguir robustez e maior produtividade dos recursos disponíveis por meio da economia de escala é, em geral, um argumento clássico do setor industrial quando se defronta com a razão financeira. Esta prefere buscar produtividade por intermédio de mecanismos de mercado: a concorrência extrai o melhor dos agentes, obrigando-os a, como quer a linguagem indígena do espaço financeiro, "correr atrás do prejuízo". E mais do que isso, em geral os financistas e os economistas que os vocalizam tendem a desbancar os argumentos baseados na economia de escala, vendo neles principalmente uma desculpa para mascarar o excesso de burocracia, a falta de comprometimento com a lucratividade das operações empresariais e, portanto, o mau uso dos recursos econômicos axiomaticamente escassos e a consequente queda de produtividade. Para eles, o protótipo da boa organização é aquela "enxuta", implicitamente pequena, na qual os incentivos propiciados pela concorrência têm mais condições de prevalecer (Douglas, 1996; Grün, 1999).

É claro que não podemos exigir coerência lógica ou semântica dos banqueiros e seus arautos. Mais que isso, como mostra Lordon para a França contemporânea, os grandes banqueiros têm uma especial capacidade de travestir e envelopar os seus idiossincráticos interesses particulares e políticos menos defensáveis numa argumentação que parece a da lógica econômica. Entretanto, ela se desnuda rapidamente quando os interesses políticos ou ameaças a projetos pessoais se alteram, pois as argumentações mudam junto, e mesmo se opõem (Lordon, 2002).

Além do aparente imbróglio, podemos extrair algumas consequências sociológicas do uso da argumentação "fora do lugar" da economia de escala. Ela distancia os banqueiros tradicionais das posturas mais radicalmente financistas, ou do chamado "fundamentalismo de mercado", ao mesmo tempo em que sugere a possibilidade de a "economia de escala" baixar o preço do dinheiro enquanto produto. Além disso, nada mais natural do que nossos banqueiros desejarem se distanciar daqueles que são imputados como os causadores da crise. E essa distinção se realiza tanto na esfera ideológica quanto na comercial. Em períodos de euforia financeira, o "arrojo" e a "novidade" fazem parte de um estilo de argumentação sincrônico e são louvados como as características mais favoráveis dos financistas, que elevam seus investimentos aos mais altos patamares de rentabilidade - e a sociedade ao rendimento mais elevado de suas potencialidades. Mas, no momento da crise, "arrojo" e "novidade" viram sinônimos de "desregramento" e "aventu- 
ra". E "economia de escala" é um argumento diacrônico, que só pode ser utilizado pelos grandes banqueiros (e não pelos financistas de vanguarda) e remete à ordem industrial, à tradição e segurança da vida econômica regrada e previsível (Boltanski e Thévenot, 1991; Douglas, 1996). Assim fazendo, os banqueiros também se aproximam dos industriais e mesmo dos governantes, enfraquecendo a crítica (e o argumento) da oligopolização e isolando a crítica adversa.

Nesse processo os "jovens banqueiros" são deixados para trás, tanto ideologicamente quanto na mais dura esfera comercial: os clientes fogem deles. Como ficam, então, as inovações que, pelo menos até agora, são eles que trazem para o campo? O campo das finanças denomina "inovações" os novos títulos de crédito - genericamente, papéis, que sistematicamente são concebidos com a intenção declarada de conferir maior liquidez e segurança à vida econômica, transferindo e pulverizando os seus riscos e liberando mais recursos para aplicações que redundem em aceleração das atividades. Quando se escuta o termo "inovação", normalmente ele é associado ao desenvolvimento científico e tecnológico, que se traduz em progresso, melhoria das condições de vida e de convívio. "Inovação financeira" é, assim, uma expressão positiva, pelo menos no período anterior à crise. Um dos primeiros efeitos do desenvolvimento da crise foi provocar um efeito de suspeição sobre a ideia de "inovação financeira", quando a mídia se tornou veículo para muitos atores expressarem suas dúvidas quanto à qualidade das novidades introduzidas pelos financistas (Lordon, 2008; Froud et alii, 2009; Engelen et alii, 2008). Alguns desses atores já faziam críticas em períodos anteriores, mas não tinham espaço, e outros, que anteriormente eram mais simpáticos às causas das finanças, passaram a criticá-las, em especial os agentes governamentais de diversos países, inclusive o presidente Lula, que pareciam reféns do campo financeiro, alçaram o nível de suas críticas que em momentos anteriores pareciam esquecidas ou "guardadas na gaveta" (Alencar, 1/3/2009; Sawer, $5 / 4 / 2008)$. Num momento seguinte, aparece a imprensa de negócios. Nos periódicos mais respeitáveis sempre houve um crítico de plantão, mas a té a eclosão da crise, ele era pouco saliente ou, pior, as advertências sobre a "exuberância irracional" dos mercados tinham pouca audiência e eram associadas ao rancor dos perdedores na ordem financei$\mathrm{ra}^{14}$.

Uma vez eclodida, a crítica ganha algum espaço. E mais uma vez observamos como se fazem as coisas com as palavras: nesse quadro, di- 
minui a complacência taxonômica que aproxima as novidades financeiras das inovações científicas e tecnológicas. Em termos práticos, uma vez desfeita essa aproximação, cada novo papel emitido por um agente financeiro, ou mesmo aqueles ainda não totalmente conhecidos, encontrarão um ambiente desfavorável, no qual a desconfiança será a primeira reação dos diversos agentes estatais e intermediários que precisam referendar a qualidade do produto para que ele entre no leque de alternativas seguras de investimento ${ }^{15}$. A primeira reação a essa tendência é uma "simplificação" dos produtos financeiros, no sentido de torná-los mais evidentes para o investidor não profissional e, consequentemente, diminuindo o fundo de comércio dos produtores de papéis mais sofisticados ${ }^{16}$. Outra reação se coaduna com o tópico "economia de escala": como no exemplo acima citado, dos grandes bancos brasileiros que adquirem as carteiras de crédito ao consumidor dos bancos pequenos, também no mercado internacional as grandes empresas financeiras se aproveitam da crise para absorver as corretoras menores que apresentam boas performances ou são especializadas em algum produto com demanda crescente (MacDonald, 18/6/2009).

Nesse ponto é importante lembrar que os administradores de investimentos são altamente constrangidos por regras de isomorfismo, que na maioria das situações os obrigam a "seguir a manada" e agir de acordo com seus pares, uma vez que problemas encontrados em decisões de investimentos diferentes das tendências do mercado, quando fracassadas, inculpam quem as decidiu e programou. E o mesmo não se aplica a fracassos ocorridos quando as decisões foram tomadas seguindo aquele vetor. Assim, agir contra as tendências mais claras de um mercado, principalmente quando os riscos de tal ação são públicos, é um procedimento duplamente arriscado (Power, 2006). No contexto da crise, as capacidades analíticas e de convencimento do gestor de fundos de investimentos, ou do conselheiro individual, mesmo se utilizadas à exaustão, não serão suficientes para fazer retornar a demanda por produtos financeiros complexos.

\section{CONCLUSÃO}

Traçado o quadro geral, vemos que a crise recente recoloca uma tendência ao repúdio da "criatividade financeira" e a tentativa de volta a períodos anteriores, nos quais "ao invés da sociedade servir os financistas, esses é que serviam a todos". Essa temática é recorrente nos períodos de crise aguda e nos imediatamente posteriores (Cowing, 1965). 
Mas o campo financeiro tem uma lógica incontornável, que entrelaça seus participantes e seus destinos. A complacência taxonômica não surge por acaso. Diversas inovações tecnológicas recentes foram propiciadas por formas de investimento inovadoras, realizadas pelos nossos financistas de vanguarda por meio do "venture capital". No espaço especificamente brasileiro, o processo de privatização das estatais nos anos 1990 também dependeu de uma complexa engenharia financeira inexistente até então. Evidentemente, podemos pensar que os governos e suas agências de fomento poderão ocupar esse espaço, como já vemos atualmente o BNDES atuar por intermédio da BNDESpar, que centraliza as participações do banco em investimentos de risco, principalmente por meio de private equities ${ }^{17}$. Boa parte do capital amealhado para financiar o boom recente dos biocombustíveis, uma das principais políticas de fomento do governo Lula, é financiada ou alavancada pelo banco por meio dessa engenharia financeira complexa, que assim deixa de ser um instrumento específico dos novos banqueiros (Mundo Neto, 2008). Num plano complementar, assistimos recentemente aos fundos de pensão das empresas estatais, dirigidos por ex-sindicalistas próximos do governo Lula, aceitarem e incorporarem a inovação das private equities, após um longo período de desconfiança e também depois que esse dispositivo financeiro se "tropicalizou" nas mãos de financistas com sensibilidade diferente do famigerado Daniel Dantas (Fortunato e Camba, 8/8/2003; Martins, 27/4/2006). Nesse quadro, não parece uma suposição razoável pensar que as inovações financeiras possam ser postas de lado; tampouco imaginar que elas possam ser postas em prática sem a colaboração de membros da "vanguarda financeira", ela mesma já suficientemente diferenciada para incorporar a dinâmica, a demanda e as sensibilidades dos outros subespaços do campo (Grün, 2009b). E assim se colocam os limites e os nexos principais da crise financeira e seus efeitos na sociedade brasileira.

Podemos, então, notar a ação persistente do campo financeiro, moldando e explicando as ações e configurações recentes. Não importando muito suas afinidades ou desavenças iniciais, ele enlaça os indivíduos e grupos e produz sentido. Esse sentido engendra e legitima produtos, posturas e carreiras, além de induzir e justificar tomadas de posição e inflexões de fora para dentro do campo financeiro. O sentido não é integralmente compartilhado, mas quando examinamos eventos como a crise financeira internacional, é sociologicamente necessário dar ênfase à parcela de consenso que ele engendra. Reparemos que as duas soluções polares, normalmente expostas pelas correntes de direi- 
ta e de esquerda não integradas ao campo financeiro, podem ser lançadas, mas o campo trabalha para descartá-las. A tradicional postura direitista de fazer funcionar o moral hazard, posta em prática pelo governo republicano norte-americano de George W. Bush para o caso Lehmann Brothers é registrada sistematicamente como deflagrador ou, pelo menos, como um dos principais complicadores da crise atual (Sorkin, 14/9/2008). A postura inicial análoga do governo conservador alemão diante da crise também foi estigmatizada e "enquadrada" (BBC, 6/10/2008; Dempsey e Kulish, 29/3/2009). Do outro lado do tabuleiro, a estatização dos serviços financeiros, típico reflexo das esquerdas tradicionais, também está no rol das posturas "insensatas" e, como vimos no nosso exemplo do Banco do Brasil e em diversos momentos do debate internacional sobre a crise, contra ela se joga a memória negativa do comunismo (Ribeiro, 2/3/2009; Wilchins, 16/1/2009; Karydakis, 17/2/2009).

A cronologia da crise no Brasil, ainda que necessariamente parcial, entre outros motivos porque nada pode nos assegurar que ela já tenha mostrado todas as suas facetas no momento em que escrevemos, indica que seus desdobramentos são subordinados à disputa cultural e ideológica que atingiu intensidade inédita desde a ascensão de Lula, particularmente depois dos escândalos de 2005. O campo financeiro produz e incorpora sentido produzido alhures, e vem daí a força ou a fraqueza que, em última instância, irão decidir a sua autonomia, a riqueza e status de seus participantes e as formas que irão produzir o futuro do país. A primeira onda de choque foi bem absorvida pelo seu setor estabelecido, que "lucrou" com a concentração bancária e por meio dela impôs condições estruturais ainda mais favoráveis nas suas disputas com o governo e outros atores econômicos. Mas a reação não tardou e o debate político se reacendeu em proporções inéditas, ameaçando o predomínio das finanças. A retórica empregada de explicar a nova situação e dar conta das críticas foi construída em torno da ideia de "economia de escala", que normalmente é vocalizada pelo setor industrial e outros grupos que não participam do mesmo espaço e por vezes se opõem aos seus produtos. Ela sinalizou uma variante da mesma estratégia de compromisso com outros setores sociais que sustenta a "responsabilidade social e ambiental", indicando que o "fundamentalismo de mercado" que caracterizou a financeirização dos últimos anos talvez esteja se desvanecendo. Mas essa estratégia se choca com a dinâmica fundamental de autonomização do campo, que ainda tem combustível. 
Nas esferas política e cultural, temos um resultado palpável: discute-se se o Plano de Aceleração do Crescimento (PAC) está ou não se concretizando, se ele poderia ou não contar com maiores recursos se o governo federal "enxugasse a máquina", mas a pertinência do papel indutor do Estado na economia ficou bem estabelecida. Da mesma maneira, no período que estudamos não se ousa mais questionar a necessidade dos bancos estatais para a economia brasileira. Essa configuração contrasta com aquela em que vivemos durante os governos de Cardoso e que perdurou até 2006, e altera drasticamente as referências fundamentais que balizam a atividade econômica.

Essa situação é apenas conjuntural ou vai perdurar? O setor financeiro conseguirá restabelecer o "fundamentalismo de mercado" como ideologia dominante? Ou podemos pensar num "novo paradigma financeiro" que abandonaria aquela tendência mais exacerbada? O caso brasileiro é bastante interessante porque o pano de fundo de um governo oriundo da esquerda do espectro político acabou engendrando um tipo específico de dominação financeira, na qual o papel dos intermediários oriundos dos espaços político, sindical e das organizações não-governamentais é mais saliente e direto. Essa situação pode se estabilizar ou é totalmente dependente do governo federal favorável àqueles agentes? As evidências que reuni sugerem que a dinâmica cultural é mais importante do que normalmente se considera, mas a "prova do pudim" só pode ser a observação do campo financeiro num possível próximo governo menos comprometido com aqueles atores e suas causas.

(Recebido para publicação em agosto de 2009)

(Reapresentado em junho de 2010)

(Aprovado para publicação em junho de 2010) 


\section{Roberto Grün}

\section{NOTAS}

1. Uma introdução da época, evidentemente causídica (e que valeria a pena discutir o porquê da sua permanência no site), pode ser encontrada em http://www.bcb.gov. br/?PROER (acessado em 8 de agosto de 2009).

2. Segundo o dicionário econômico de The Economist: "moral hazard é um dos dois principais tipos de falha de mercado. Significa que as pessoas que têm seguro podem assumir maiores riscos do que aqueles que não o têm, porque eles sabem que estão protegidos, por isso o segurador pode acabar tendo de bancar mais demandas do que havia negociado". Ver em http://www.economist.com/RESEARCH/ECONOMICS/ alphabetic.cfm?letter=M\#moralhazard (acessado em 12 de junho de 2009, tradução minha).

3. A história nos fornece vários "exemplos de referência" de situações análogas. Assim, temos as análises de Duby sobre codificação e enrijecimento do feudalismo europeu justamente quando seus fundamentos estavam esmaecendo, e a de Reddy, das habitualidades contratuais e do senso de justiça nas relações de trabalho na França pós-revolucionária (Duby, 1978; Reddy, 1984). Um ponto acessório é que tais mudanças são particularmente sentidas no espaço da produção cultural da sociedade, pois intelectuais estatutários perdem a segurança tradicional ligada ao monopólio das formas de expressão que entram em decadência. A sua reação à perda acaba gerando espasmos que repercutem em toda a sociedade, como nos mostram os escândalos que têm sacudido a cena política e midiática do Brasil dos governos Lula (Grün, 2008a; 2008b).

4. Podemos mesmo dizer que a generalidade dessa posição separa a sociologia econômica baseada em Bourdieu de diversas outras propostas mais ou menos contemporâneas, em especial aquelas diretamente inspiradas no marxismo (Bourdieu, 2000; Lebaron, 2000).

5. Ainda que os intelectuais "orgânicos" das finanças tentem, com afinco, afirmar essa realização. Aos meus olhos o melhor exemplo, devidamente traduzido e publicado no Brasil é Bernstein (1992; 2007).

6. Esses estabelecimentos são evidentemente conglomerados financeiros mais amplos, cuja face mais visível é o banco comercial, ao qual, durante o regime militar, foram acrescidos diversos outros serviços financeiros como seguros, câmbio, leasing etc. (Macarini, 2007). Expus sistematicamente a cartografia desse espaço, a articulação sociológica entre os atores que trafegam no espaço financeiro e a tensão entre o setor estabelecido e os diversos segmentos da sua vanguarda em Grün (2004; 2007b).

7. E diversas monografias acadêmicas em curso mostram como setores menos privilegiados da população brasileira também entram na mesma órbita. Elas revelam, ao mesmo tempo, algumas facetas específicas do processo, bem como a própria sensibilidade social e intelectual pelo processo que atravessamos. Os resultados parciais de algumas delas pode ser encontrado em Bueno (2008), Leite e Melo (2008) e Bonaldi (2009).

8. Posteriormente, pipocaram notícias sobre problemas análogos em outras empresas tradicionais, como por exemplo, o grupo Vicunha, proprietário da Companhia Siderúrgica Nacional (Adachi, 14/5/2009). 
9. Em especial, a fusão entre os bancos Itaú e Unibanco. Factualmente, ela foi facilitada pela "corrida" contra o Unibanco no início da crise (Balarin, 10/11/2009). Mas a solução proposta pelos grupos proprietários dos dois conglomerados, que implicava um aumento significativo da concentração bancária, só foi aceita no pano de fundo do medo generalizado de uma corrida contra o sistema financeiro como um todo.

10. A generalidade do problema pode ser acompanhada complementarmente no texto inglês de (Folkman. Sukhdev e Williams, 2006) refletindo um contexto de forte autonomia financeira, e no francês de (Montlibert, 2007) para um espaço mais regulado externamente. Sobre o papel das agências de rating na crise dos subprimes, ver (Poon, 2009). No Brasil há, entre outros, trabalhos sobre consultores empresariais que fazem circular a cultura gerencial entre empresas (Donadone, 2009); sobre "gurus financeiros" que traduzem conteúdos oriundos do espaço empresarial e financeiro para o mundo doméstico (Leite, 2009), além de trabalhos em curso sobre jornalistas econômicos (Pedroso Neto, 2010).

11. Apresento uma cartografia mais recente do espaço financeiro, com ênfase no subespaço dos inovadores e na tensão social que engendra a forma particular que os fundos de private equity apresentam no Brasil em (Grün, 2009b).

12. Outro ponto notável do período é a pouca atenção da mídia sobre a possível, e muito provável, ligação do execrado banqueiro Daniel Dantas com outros participantes do campo. Tudo se passa como se nosso "boneco de Judas" fosse um ator completamente independente do espaço no qual nasceu e se desenvolveu e que suas atividades devem ser catalogadas apenas no espaço policial ou político partidário. Entretanto, dados os mecanismos atuais de compensação de riscos e distribuição de lucros, o banco de Dantas certamente empresta, toma emprestado, terceiriza e realiza diversas outras operações em cooperação com outras organizações financeiras. A omissão desse encadeamento óbvio é então um dado claro que indica o controle da agenda e, mais genericamente, dos enquadramentos possíveis para a sociedade brasileira pensar a crise.

13. As idades sociológicas não se confundem com a cronologia física dos anos após-nascimento, mas com as trajetórias sociais dos indivíduos e grupos. Dessa maneira, para o que interessa na explicação sociológica, nossa vanguarda financeira, constituída por banqueiros de primeira geração que propõem novos produtos e formas de conduta, será jovem enquanto ocupar essa posição no campo financeiro (Attias-Donfut, 1988; Mannheim e Mauger, 1990; Grün, 1993).

14. Martin Wolf, jornalista do Financial Times, e os economistas Nouriel Roubini, Robert Shiller e Paul Krugman, traduzidos e reproduzidos em muitas línguas e veículos são, talvez, os mais conhecidos indivíduos dessa espécie. Além disso, os acima citados Delfim Neto e Georges Soros são também invocados e solicitados.

15. Na linguagem interna do espaço, é a volta ao plain vanilla (por analogia aos sorvetes de massa), os produtos mais conhecidos e menos sofisticados, que podem ser compreendidos e operados por investidores e profissionais menos preparados.

16. Lordon (2008) faz um bom registro crítico e acessível sobre a construção e a lógica desses papéis financeiros.

17. E, como vimos, a crítica dos players privados não tarda a chegar, e através de Armínio Fraga, um porta-voz de peso nesse espaço (Moura e Rosas, 7/8/2009). 


\section{Roberto Grün}

\section{REFERÊNCIAS BIBLIOGRÁFICAS}

ADACHI, Vanessa. (2009), “Crise Cambial: depois de negar perda com derivativos, Vicunha Têxtil vai pagar dívida com desconto. Steinbruch pagará R\$ $180 \mathrm{mi}$ ao Merrill". Valor Econômico, 14 de maio.

ALENCAR, Kennedy. (2009), "Bancos fazem lobby com Lula contra demonização”. Folha Online, 1o de março.

. (2006), "Durante crise, ministros sugeriram renúncia". Folha de S. Paulo, 30 de outubro.

ATTIAS-DONFUT, Claudine. (1988), Sociologie des Générations l'Empreinte du Temps. Paris, Presses Universitaires de France.

AUSTIN, John. (1962), How to Do Things with Words. Oxford, Clarendon Press.

BALARIN, Raquel. (2009). "Há um ano, ataque abalou o Unibanco". Valor Econômico, 10 de novembro.

BARBOSA, Marina. (2008), “Votorantim perde R $\$ 2,2$ bi com derivativos". O Estado de S. Paulo, 11 de outubro.

BBC (British Broadcasting Corporation). (2008), "Germany clinches bank rescue deal". $B B C$ News, 6 de outubro.

BECKER, Jo. (2008). “White House philosophy stoked mortgage bonfire”. The New York Times, 20 de dezembro.

BERNSTEIN, Peter. (1992), Capital Ideas: The Improbable Origins of Modern Wall Street. New York, Free Press.

. (2007), História do Mercado de Capitais: O Impacto da Ciência e da Tecnologia nos Investimentos. São Paulo, Campus.

BOHN, Cornelia. (2006), “Une Société Mondiale: Les Concepts de Société Opératoires dans les Théories Sociales de Bourdieu et de Luhmann" , in H.-P. Müller e Y. Sintomer (eds.), Pierre Bourdieu, Théorie et Pratique: Perspectives Franco-Allemandes. Paris, La Découverte, pp. 101-124.

BOLTANSKI, Luc e CHIAPELLO, Eve. (1999), Le Nouvel Esprit du Capitalisme. Paris, Gallimard.

BOLTANSKI, Luc e THÉVENOT, Laurent. (1991), De la Justification: Les Économies de la Grandeur. Paris, Gallimard.

BONALDI, Eduardo Vilar. (2009), O Investidor Leigo e o Mercado de Ações: Sobre a Noção de um Dinheiro Especial, as Associações com os Jogos de Azar e as Primeiras Representações da Crise Financeira. Trabalho apresentado no I Seminário Nacional de Sociologia Econômica. Florianópolis, 19-22 de maio.

BOURDIEU, Jerôme; HEILBRÖM, Johan e REYNAUD, Bénédicte. (2003), “Les Structures Sociales de la Finance". Actes de la Recherche en Sciences Sociales, no 146-147, pp. 3-7.

BOURDIEU, Pierre. (1976), "Les Modes de Domination”. Actes de la Recherche en Sciences Sociales, nos 2-3, pp. 122-132. 
A Crise Financeira, a Guerra Cultural e as Transformações do Espaço...

. (1989), La Noblesse d'Etat: Grandes Écoles et Esprit de Corps. Paris, Minuit.

(1992), Les Règles de l'Art: Genèse et Structure du Champ Littéraire. Paris, Seuil.

(1997), Méditations Pascaliennes. Paris, Seuil.

(2000), Les Structures Sociales de l'Économie. Paris, Seuil.

BUENO, Arthur. (2008), As Paixões do Homo Oeconomicus: Os Devedores Anônimos e as Condições Emocionais da Racionalidade Econômica. Trabalho apresentado no XXXII Encontro Anual da Anpocs, Caxambu, MG, 27-31 de outubro.

CAMAROTTO, Murillo. (2009), "Setubal Abandona Polêmica dos Juros". Valor Econômico, 20 de agosto.

CAMBA, Daniela. (2009), "Ingerência Política Volta a Assustar". Valor Econômico, 9 de abril.

CANÇADO, Patrícia e MODÉ, Leandro. (2008), “Brasil está entre os mais expostos aos fundos de Madoff: Produtos do ex-presidente da Nasdaq eram oferecidos no País por vários canais; procura por advogados cresce". O Estado de S. Paulo, 18 de dezembro.

CARNEIRO, Dionísio Dias. (2008), "Contra a crise, licença para matar?". O Estado de S. Paulo, 2 de novembro.

CARVALHO, Maria Cristina. (2009), “Ganho do Bonsucesso cresce 7 vezes”. Valor Econômico, 12 de agosto.

CHAN, Sewell. (2010), "Dodd calls Obama Plan too Grand". The New York Times, 2 de fevereiro.

CIARELLI, Mônica. (2009), “BNDES Precisa Começar a 'Desmamar' o Mercado, diz Fraga. Armínio Fraga diz que Banco Precisa Ter Cuidado para não Inibir Desenvolvimento do Mercado de Capitais". Agência Estado Online, 6 de agosto.

CONSERVATIVE PARTY. (1976), "The Right Approach (Conservative policy statement)". Margaret Thatcher Fondation, 4 de outubro.

COWING, Cedric. (1965), Populists, Plungers, and Progressives. A Social History of Stock and Commodity Speculation, 1890-1936. Princeton, Princeton University Press.

CUCOLO, Eduardo. (2009), "BB vai pressionar e fazer bancos privados 'comerem poei$\mathrm{ra}^{\prime}$, diz Mantega". Folha Online, 13 de agosto.

DASTON, Lorraine e GALISON, Peter. (2007), Objectivity. New York e Cambridge, Zone Books/MIT Press.

DEMPSEY, Judy e KULISH, Nicholas. (2009), “Merkel Is Set to Greet, and then Resist, Obama". The New York Times, 29 de março.

DEZEM, Vanessa. (2009), "Setúbal Admite Aquisições no Exterior em 2011". Valor Econômico, 12 de agosto.

DONADONE, Júlio César. (2009), “Brazilian Consulting Cartography and the New Recontextualization and Internationalization of Interchanges and Managerial Contents". Corporate Ownership \& Control, vol. 6, pp. 35-55.

DOUGLAS, Mary. (1996), Thought Styles: Critical Essays on Good Taste. London, Thousand Oaks, Sage. 


\section{Roberto Grün}

e NEY, Steven. (1998), Missing Persons: A Critique of the Social Sciences. Berkeley/New York, University of California Press/Russell Sage Foundation.

DUBY, Georges. (1978), Les Trois Ordres ou l'Imaginaire du Féodalisme. Paris, Gallimard.

ENGELEN, Ewald; FROUD, Julie; LEAVER, Adam e WILLIAMS, Karel. (2008), “Financial Innovation: Frame, Conjuncture and Bricolage". Working Paper no 59, Centre for Research on Socio-Cultural Change (CRESC).

ESTADO ONLINE. (2009), “Febraban: Inadimplência Vai Determinar Spread". Acessado em 2 de fevereiro.

FLECK, Ludvik. (1979) [1935], Genesis and Development of a Scientific Fact. Chicago, University of Chicago Press.

FLIGSTEIN, Neil. (2009), The Anatomy of Mortgage Securization Crisis. Manuscrito. Disponível em http:/ / sociology.berkeley.edu/profiles/fligstein/pdf/The\%20 Anatomy\%20of\% 20the\%20Mortgage\%20Securitization\%20Crisis5.pdf.

FOLHA ONLINE. (2008), “Itaú e Unibanco Anunciam Fusão e Criam Maior Grupo Financeiro do Hemisfério Sul". 3 de novembro.

(2008), “Banco do Brasil Fecha Compra da Nossa Caixa por R \$ 5,4 Bilhões". 20 de novembro.

FOLKMAN, John; SUKHDEV, Johal e WILLIAMS, Karel. (2006), “Working for Themselves?: Capital Market Intermediaries and Present Day Capitalism". Working Paper no 25, CRESC, Disponível em http:/ / www.cresc.ac.uk/publications/papers.html).

FORTUNATO, Patrícia e CAMBA, Daniele. (2003), "Fundos de Pensão Divergem sobre Investimento em Private Equity: Pimentel, presidente da Abrapp, Defende Investimentos de Menor Risco para os Fundos de Pensão". Valor Econômico, 8 de agosto.

FRANCO, Gustavo. (2008), “Keynes é Nosso". Folha de S. Paulo, 1 de novembro.

FRIEDLANDER, David e GRINBAUM, Ricardo. (2008), “Já Tomamos Tombos Piores". Valor Econômico, 30 de novembro.

FROUD, Julie et alii. (2009), “Escaping the Tyranny of Earned Income? The Failure of Finance as Social Innovation". Working Paper no 66, Centre for Research on Socio-Cultural Change.

GALHARDO, Ricardo. (2008), "Lula: Crise é Tsunami nos EUA e, se Chegar ao Brasil, Será 'Marolinha'". O Globo, 4 de outubro.

GALVÃO, Andrea. (2009), "Governo Troca o Comando do BB". Valor Econômico, 9 de abril.

GARCIA, Marie-France. (1986), “La Construction Sociale d'un Marché Parfait: Le Marché au Cadran de Fontaines-en-Sologne". Actes de la Recherche en Sciences Sociales, no 65, pp. 2-13.

GIGERENZER, Gerd e GOLDSTEIN, Daniel. (1996), “The Mind as a Computer: The Birth of a Metaphor". Creativity Research Journal, no 9, pp. 131-144.

GODOY, Denise. (2009), “'Spread’ Bancário no Brasil é 11 vezes o dos Países Ricos. Diferença entre os Juros Captados e os Cobrados pelos Bancos Brasileiros é a mais Alta Praticada no Mundo, aponta Estudo". Folha de S. Paulo, 1o de fevereiro. 
e IGLESIAS, Simone. (2009), "Crise Foi Causada por 'Gente Branca de Olhos Azuis', diz Lula. Ao Lado de Premiê Britânico, presidente Afirma que Pobres, $\mathrm{Ne}$ gros e Índios não Podem Pagar a Conta da Especulação Financeira". Folha de S. Paulo, 27 de março.

GOIS, Chico de, JUNGBLUT, Cristiane e DAMÉ, Luiza. (2007), “Lula Sanciona Lei do Saneamento e Abre Caminho para Investimentos: Ao Aprovar o Marco Regulatório do Setor, Presidente Faz Críticas à Privatização". O Globo, 6 de janeiro.

GOODMAN, Nelson. (1978), Ways of Worldmaking. Indianapolis, Hackett Pub. Co.

GRINBAUM, Ricardo. (2008), "'Vamos Comprar as Carteiras de Crédito dos Bancos Pequenos'. Segundo Setubal, os grandes bancos estão atendendo à determinação do BC para injetar recursos nas instituições menores". O Estado de S. Paulo, 7 de novembro.

GRÜN, Roberto. (1993), "Sobre o Envelhecimento Gerencial”. Revista de Administração de Empresas, no 33, pp. 44-63.

(1999), "Modelos de Empresa, Modelos de Mundo: Sobre Algumas Características Culturais da Nova Ordem Econômica e da Resistência a Ela". Revista Brasileira de Ciências Sociais, no 14, pp. 121-140.

. (2004), “A Evolução Recente do Espaço Financeiro no Brasil e Alguns Reflexos na Cena Política”. DADOS, vol. 47, no 1, pp. 5-47.

. (2005a), “'Apagão Cognitivo': A Crise Energética e sua Sociologia”. DADOS, vol. 48, no 4, pp. 891-928.

(2005b), “Convergência das Elites e Inovações Financeiras: A Governança Corporativa no Brasil". Revista Brasileira de Ciências Sociais, ano 20, no 58, pp. 67-90.

. (2007a), "Decifra-me ou Te Devoro: As Finanças e a Sociedade Brasileira". Mana, no 13, pp. 381-410.

(2007b), "Entre a Plutocracia e a Legitimação da Dominação Financeira". Revista Brasileira de Ciências Sociais, ano 22, no 65, pp. 85-107.

. (2008a), “Escândalos, Marolas e Finanças: Para uma Sociologia da Transformação do Ambiente Econômico". DADOS, vol. 51, no 2, pp. 313-352.

. (2008b), "Guerra Cultural e Transformações Sociais: As Eleições Presidenciais de 2006 e a 'Blogosfera'". Sociedade e Estado, no 23, pp. 621-666.

. (2009a), "Le Brésil et les Brésiliens dans la Globalisation Financière". Cahiers de la Recherche sur l'Éducation et les Savoirs, no 2 hors-série.

(2009b), “Financeirização de Esquerda? Frutos Inesperados no Brasil do Século XXI". Tempo Social, no 21, pp. 153-184.

GUEX, Sébastien. (2003), “La Politique des Caisses Vides: État, Finances Publiques et Mondialisation". Actes de la Recherche en Sciences Sociales, nos 146-147, pp. 51-61.

HACKING, Ian. (2002), "Inaugural Lecture". Chair of Philosophy and History of Scientific Concepts at the Collège de France, 16 of January, 2001". Economy \& Society, vol. 31, pp. 1-14.

HEFFER, Simon. (2008), “Financial Crisis: We're All Socialists Now, Comrade”. Business Week, 9 de outubro. 


\section{Roberto Grün}

HIRSCHMAN, Albert. (1991), The Rhetoric of Reaction: Perversity, Futility, Jeopardy. Cambridge, MA., Belknap Press.

HUNTER, James. (1991), Culture Wars: The Struggle to Define America. New York, Basic Books.

IGLESIAS, Simone e D'AMORIM, Sheila. (2009), “Governo Acerta Redução no Ritmo da Queda dos Juros: Meirelles diz a Lula que Agressividade agora Traz Risco de Alta da Taxa em 2010; Petista Afirma que o BC Tem Condições de Promover Nova Queda na Selic Hoje e que Autoridade Monetária Fará o 'Melhor para o Brasil'". Folha de S. Paulo, 22 de julho.

JARDIM, Maria Aparecida. (2007), Entre a Solidariedade e o Risco: Sindicatos e Fundos de Pensão em Tempos de Governo Lula. Tese de doutorado em Ciências Sociais, Programa de Pós-Graduação em Ciências Sociais, Universidade Federal de São Carlos, São Carlos, SP.

JOSEPH, John e OCASIO, William. (2005), “Cultural Adaptation and Institutional Change: The Evolution of Vocabularies of Corporate Governance, 1972-2003". Poetics, vol. 33 , n으 3-4.

KARYDAKIS, Anthony. (2009), “In Praise of Nationalizing Banks: In Some Situations, it Offers the Best Hope of Ending the Paralysis. But its Associations with Socialism in the U.S. May Be Getting in the Way of a Good Solution". Fortune, 17 de fevereiro.

LAKOFF, George. (1996), Moral Politics: What Conservatives Know that Liberals Don't. Chicago, The University of Chicago Press.

LAMUCCI, Sergio. (2006), “Agenda Liberal Afugenta Presidenciáveis". Valor Econômico, 24 de outubro.

LEBARON, Frédéric. (2000), La Croyance Économique: Les Économistes entre Science et Politique. Paris, Seuil.

LEITE, Elaine. (2009), Finanças Pessoais, Dinheiro e Promessas Exuberantes. Trabalho apresentado no I Seminário Nacional de Sociologia Econômica. Florianópolis, UFSC, 19-22.

e MELO, Natália. (2008), “Uma Nova Noção de Empresário: A Naturalização do ‘Empreendedor'”. Revista de Sociologia e Política, vol. 16, pp. 35-47.

LEONEL, Josué e TAVARES, Rita. (2003), “Fechado Acordo para Votar Mudança no Sistema Financeiro, diz petista". O Estado de S. Paulo, 26 de março.

LEOPOLDO, Ricardo. (2009), “Redução de Spread de Bancos Públicos Não É Sustentável: Enquanto Bancos Privados Subiram Juros para Enfrentar a Crise, diz Setubal, Bancos Públicos Cortaram Algumas Taxas". O Estado de S. Paulo, 12 de agosto.

LORDON, Frédéric. (2002), La Politique du Capital. Paris, Odile Jacob.

. (2008), Jusqu'à Quand?: Pour en Finir avec les Crises Financières. Paris, Raisons d'Agir.

MACARINI, José Pedro. (2007), “A Política Bancária do Regime Militar: O Projeto de Conglomerado (1967-1973)". Economia e Sociedade, vol. 16, pp. 343-369.

MACCORMICK, Paul. (1996), Starmaking Realism, Anti-Realism, and Irrealism. Cambridge, MA., MIT Press. 
MACDONALD, Alistair. (2009), "Regulatory, Investor Demands to Favor Hedge M\&A". Agência Reuters, 18 de junho.

MACKENZIE, Donald. (2006), An Engine, Not a Camera: How Financial Models Shape Markets. Cambridge, MA., MIT Press.

(2009), The Credit Crisis as a Problem in the Sociology of Knowledge. Manuscrito. Disponível em http://www.sps.ed.ac.uk/ãdata/assets/pdfãfile/0019/36082/CrisisNew19.pdf.

MANNHEIM, Karl e MAUGER, Gérard. (1990), Le Problème des Générations. Paris, Nathan.

MARTELLO, Alexandro. (2009), “Bancos Podem Abater Compra de Carteira de Crédito no Compulsório até Junho: Medida foi Regulamentada nesta quinta-feira pelo Banco Central. Prazo original para abatimento terminaria no fim do mês de março". Agência G1 (O Globo), 26 de março.

MARTINS, Ricardo Malavazi. (2006), Petros e a Indústria de Venture Capital e Private Equity. (Diversificação e perspectiva de longo prazo). III Ciclo de Debates sobre Venture Capital no Brasil, Rio de Janeiro, 27 de abril.

MAUSS, Maurice e LÉVI-STRAUSS, Claude. (1983), Sociologie et Anthropologie. Paris, Presses Universitaires de France.

MONTEIRO, Luciana. (2009), “Madoff Faz Cair Aplicação no Exterior: Na Prática, a Teoria é Outra". Valor Econômico, 20 de fevereiro.

MONTLIBERT, Christian. (2007), Les Agents de l'Économie: Patrons, Banquiers, Journalistes, Consultants, Élus: Rivaux et Complices. Paris, Raisons d'Agir.

MOREIRA, Ivana. (2009), “Consignado Garante Lucro a Bancos Médios: Mudança de Regras no Crédito para Pensionistas Ajudou Instituições". O Estado de S. Paulo, 12 de agosto.

MOURA, Paola e ROSAS, Rafael. (2009). “Fraga quer BNDES menos atuante". Valor Econômico, 7 de agosto.

MUNDO NETO, Martin. (2008), Desenvolvimento do Mercado do Etanol: Aproximação da Indústria Sucroalcooleira e da Indústria de Capital de Risco no Brasil. Trabalho apresentado no XXXII Encontro Anual da Anpocs, Caxambu, MG, 27-31 de outubro.

NINIO, Marcelo. (2008), “Perda Cambial Atinge mais de 200 Empresas, diz governo. Previsão é que Novos Prejuízos Milionários com Derivativos Sejam Anunciados. Grandes companhias como Sadia, Votorantim e Aracruz já informaram prejuízos com apostas erradas no mercado futuro". Folha de S. Paulo, 14 de outubro.

(2009), "Empresas Nunca Ganharam Tanto, diz Lula: Presidente pede ousadia no comércio exterior e critica 'trambique' de companhias com derivativos". Folha de $S$. Paulo, 22 de maio.

NÓBREGA, Mailson da. (1997), “O Proer Deve Continuar?”. IstoÉ, 4 de abril.

OLIVEIRA, Ribamar. (2003), “Governo já Tem Proposta para Mudar o 192”. Valor Econômico, 19 de fevereiro.

(2008), "Entrevista de Antonio Delfim Neto a Ribamar Oliveira". O Estado de S. Paulo, 5 de outubro. 


\section{Roberto Grün}

ONAGA, Marcelo. (2008), “A Aposentadoria Pode Esperar". Portal Exame, 16 de outubro.

ORTONY, Andrew (ed.). (1993), Metaphor and Thought. Cambridge/New York, Cambridge University Press.

PATURY, Felipe. (2001), “O Proer, quem diria, deu lucro O empréstimo que todo mundo achava perdido tem garantias que se valorizaram 800 milhões de reais". Veja, no 717, 12 de setembro.

PEDROSO NETO, Antonio José. (2010), O Jornalismo Econômico no Brasil: Entre a Economia e a Política. Programa de Pós-Graduação em Ciências Sociais da Universidade Federal de São Carlos. Projeto em curso financiado pelo CNPq.

POON, Martha. (2009), "From New Deal Institutions to Capital Markets: Commercial Consumer Risk Scores and the Making of Subprime Mortgage Finance". Accounting, Organizations and Society, vol. 34, no 5, pp. 654-674.

POWER, Michael. (2006), “Enterprise Risk Management and the Organization of Uncertainty in Financial Institutions", in K. Knorr-Cetina e A. Preda (eds.), The Sociology of Financial Markets. Oxford/New York, Oxford University Press, pp. 250-268.

REDDY, William. (1984), The Rise of Market Culture: The Textile Trade and French Society, 1750-1900. New York/Paris, Cambridge University Press/Editions de la Maison des Sciences de l'Homme.

REHDER, Marcelo. (2009), “Fiesp Acusa Bancos de Usar Crise para Aumentar Spread: 'É uma roubalheira. No HSBC, o spread é de quase $50 \%$, e a fonte é o próprio Banco Central', diz Skaf". O Estado de S. Paulo, 13 de fevereiro.

RIBEIRO, Alex. (2009), “Lima Neto Resistiu em Baixar Juros e Ficou Enfraquecido”. Valor Econômico, 9 de abril.

RIBEIRO, Ana Paula. (2008), “Fabio Barbosa Assume Santander no Brasil”. Portal Exame, 24 de julho.

RIBEIRO, Bianca. (2009), “Lula diz que Bancos Estatais Dão Segurança ao País em Tempos de Crise". Valor Econômico, 2 de março.

RIBEIRO, Ivo. (2009), “Família Poderá Levantar R\$ 6 Bi com Venda de Ativos”. Valor Econômico, 12 de janeiro.

RIBEIRO, Sergio. (2009), “Banco do Brasil Inicia Renegociação de Dívidas dos Produtores Rurais". Agência Brasil, 5 de agosto.

RIEDER, Jonathan e STEINLIGHT, Stephen. (2003), The Fractious Nation?: Unity and Division in Contemporary American Life. Berkeley, University of California Press.

ROMERO, Cristiano. (2009), “FGI: Um Fundo para Destravar o Crédito". Valor Econômico, 12 de agosto.

ROSAS, Rafael. (2009), "Meirelles Espera Queda do Spread para Breve". Valor Econômico, 15 de abril.

SADDI, Jairo. (2009), “Algumas Respostas Regulamentares ao “To Big to Fail'”. Valor Econômico, 23 de dezembro.

SAFATLE, Claudia. (2009), "Para os Bancos, os Tempos Estão Mudando". Valor Econômico, 3 de julho. 
SALLES, Ygor. (2009), "Votorantim e Aracruz Planejam Concluir Fusão em Cinco Meses". Folha Online, 20 de janeiro.

SAPIRO, Gisèle. (2003), "The Literary Field Between the State and the Market". Poetics, vol. 31, n으 5-6, pp. 441-464.

SARDENBERG, Carlos. (2006), “O PSDB Acabou”. O Globo, 1o de novembro.

SARTORE, Marina. (2006), A Inserção da Responsabilidade Social do Setor Bancário no Contexto da Governança Corporativa. Dissertação de Mestrado, Programa de PósGraduação em Engenharia de Produção, Universidade Federal de São Carlos. São Carlos, SP.

SAWER, Patrick. (2008), “Gordon Brown Warns on Global Financial Crisis". The Daily Telegraph, 5 de abril.

SCIARRETTA, Toni. (2009), "HSBC Vê Crédito mais Escasso se BB Forçar Redução nos Juros". Folha de S. Paulo, 18 de abril.

SINCLAIR, Timothy. (2005), The New Masters of Capital: American Bond Rating Agencies and the Politics of Creditworthiness. Ithaca, NY, Cornell University Press.

SORKIN, Andrew. (2008), "Lehman Files for Bankruptcy: Merrill Is Sold". The New York Times, 14 de setembro.

SOROS, Georges. (2008), "The Crisis \& What to Do About It". The New York Review of Books, vol. 55, no 19 .

STORY, Louise; THOMAS JR., Landon e SCHWARTZ, Nelson. (2010), “Wall St. Helped Greece to Mask Debt Fueling Europe's Crisis". The New York Times, 13 de fevereiro.

TAGUIEFF, Pierre-André. (2005), La Foire aux Illuminés: Ésotérisme, Théorie du Complot, Extrémisme. Paris, Mille et Une Nuits.

TENORIO, Iberê. (2006), “Bancada Ruralista Diminui, mas Reelege seus Líderes: estudo do Diap indica que o grupo perdeu deputados (caiu de 111 para 95), mas a reeleição de líderes importantes e de expoentes do agronegócio pode garantir a manutenção da força dos defensores do latifúndio no Congresso". Agência Carta Maior, 19 de outubro.

TEREZA, Irany. (2006), “Oligopólio Freia a Queda dos Juros ao Consumidor". Agência Estado, 21 de agosto.

(2008), “Aracruz Sabia das Operações com Derivativos". O Estado de S. Paulo, 26 de novembro.

ULHÔA, Raquel. (2009), “Congresso: Para os Governistas, Manobra Regimental Atende aos Interesses da Febraban, Contrária à Lei: DEM Impede Votação do Projeto das Tarifas". Valor Econômico, 12 de agosto.

VALOR ONLINE. (2008), “Grupo Votorantim perde $\mathrm{R}$ \$2,2 bilhões ao liquidar exposição cambial". Valor Online, 10 de outubro.

VIEIRA, André. (2008a), “Apostas Financeiras Sacodem a Votorantim”. Valor Econômico, 27 de novembro.

. (2008b), "Crise Expõe Modelo de Gestão na Votorantim". Valor Econômico, 27 de novembro. 


\section{Roberto Grün}

. (2009), “Votorantim Divide Área Financeira e Cria Gestão de Riscos". Valor Econômico, 11 de fevereiro.

. (2009), “'Nova Estrutura é mais Confiável e Reduz Riscos', diz executivo do grupo". Valor Econômico, 21 de janeiro.

WEBER, Eugene. (1999), Apocalypses: Prophecies, Cults, and Millennial Beliefs Through the Ages. Cambridge, MA, Harvard University Press.

WILCHINS, Dan. (2009), “Will United States Be Forced to Nationalize Banks?". Agência Reuters, 16 de janeiro.

WILLIAMS, Karel e FROUD, Julia. (2007), "Private Equity and the Culture of Value Extraction". Working Paper no 31, CRESC, The University of Manchester.

WILLIAMS, Rhyss. (1997), Cultural Wars in American Politics: Critical Reviews of a Popular Myth. New York, Aldine de Gruyter.

WOLF, Martin. (2009), “Encolher o Capital Financeiro é a Questão: A Era Dourada de Wall Street Acabou: A Volta da Regulamentação é Causa e Consequência desta Mudança". Valor Econômico, 15 de abril.

ZELENY, Jeff. (2009), "The President Is on the Line to Follow Up on Socialism”. The New York Times, 7 de março. 
A Crise Financeira, a Guerra Cultural e as Transformações do Espaço...

\section{ABSTRACT \\ Financial Crisis, Cultural War, and Transformations in the Economic Field in Brazil in 2009}

The financial crisis that broke out in 2008-09 sparked or unveiled a series of internal transformations in the world of finance and its relations with the rest of Brazilian society, especially between the financial elites and the political field. The article aims to begin to analyze these new trends and thereby help explain some less obvious points in the concept of "field" in Bourdieu's sociology, as well as to highlight the notion of "cultural war" in the sense of demonstrating its pertinence for explaining the Brazilian social scene in recent decades.

Key words: sociology of finances; cultural war; financial crisis; financial field

\section{RÉSUMÉ}

La Crise Financière, la Guerre Culturelle et les Transformations de l'Espace Économique Brésilien en 2009

La crise financière qui a éclaté en 2008-2009 a déclenché ou mis à nu une série de transformations intérieures dans le monde des finances et des relations de ce monde avec l'ensemble de la société brésilienne, surtout dans les rapports entre les élites financières et le champ politique. Dans cet article, on cherche à saisir ces nouveautés et par leur biais, aider à expliquer certains points moins évidents de la notion de "champ" de la sociologie de Bourdieu, tout en approfondissant l'idée de "guerre culturelle" et en montrer la pertinence pour mieux comprendre la scène sociale brésilienne des dernières décennies.

Mots-clé: sociologie des finances; guerre culturelle; crise financière; champ financier 